JóZeF MARECKı OFMCap.

\title{
KONWENT KAPUCYNÓW WE LWOWIE-ZAMARSTYNOWIE (1903-1946)
}

\section{PIERWSZE FUNDACJE KAPUCYNÓW W RZECZYPOSPOLITEJ}

W 1681 roku, po kilku wcześniejszych próbach za króla Zygmunta III i Władysława IV, kapucyni osiedlili się na ziemiach polskich. Bezpośrednio po swojej elekcji Jan III Sobieski, w dniu 11 lipca 1674 roku, zwrócił się do papieża Klemensa $X^{1} \mathrm{z}$ prośbą o udzielenie pozwolenia kapucynom na przybycie do Polski. Dopiero jednak breve papieża Innocentego XI z 10 września 1680 roku zezwoliło kapucynom na założenie w Polsce dwóch klasztorów: unum quidem civitate Cracoviensi, alterum vero in oppido Varsaviensis dioecesis erigi... Budowę pierwszego klasztoru - niewielkiego

Używane skróty: AAL - Archiwum Diecezji Lwowskiej w Lubaczowie; ACC - AP sygn. 10b, Acta Capitulorum et Congregationum. 18113-1926; ACP - AP sygn. 10c, Acta Capitulorum Provinciae Cracoviensis, t. 3 (od 1927 roku); AGO - Archiwum Generale Ordinis, Roma; AKZ - Archiwum Klasztoru Kapucynów we Lwowie-Zamarstynowie (depozyt w AP); AP - Archiwum Krakowskiej Prowincji Kapucynów, Kraków; APZ - Archiwum Krakowskiej Prowincji Kapucynow - dział personalny; AZ - Archiwum Krakowskiej Prowincji Kapucynów, sygn. 24, Akla klasztoru OO. Kapucynów w Zamarstynowie. Dokumenty. Korespondencja. Inwentarze. Plany. 1903-1943; KKZ - AKZ sygn. 7, Kronika klasztoru OO. Kapucynów. Lwów na Zamarstynowie. 1904-1946; KPK - AP sygn. 45, Kronika Prowincji Krakowskiej OO. Kapucynów. 1921-1973; KZG - AGO sygn. AH 12, Uchwały z posiedzeń Kongregacji zarządu Generalnego Zakonu (1918-1939); LC - Lexicon capuccinum promptuarium historico-bibliographicum Ordinis Fratrum Minorum Capuccinorum (1525-1950), Romae 1951; APK - J.L. Gadacz, Slownik polskich kapucynów. T. 1-2. Wrocław 1985-1986.

${ }^{1}$ Emilio Altieri (1590-1676), prawnik, bp Camerino. Od 1670 był papieżem jako Klemens X. Rządy w jego imieniu sprawował kard. Paluzzi degli Albertoni. - Por. H. Stadler, Leksykon papieży $i$ soborów. Warszawa 1992, s. 153. 
hospicjum i kaplicy - rozpoczęto jednak w Warszawie. W maju 1682 r. kapucyni, mieszkając w zamku królewskim, prowadzili juź regularne duszpasterstwo wśród przebywających w Warszawie Włochów. W trzynaście lat później, w listopadzie 1695 roku, doprowadzono do końca - nie bez kłopotów - budowę klasztoru i świątyni przy ul. Miodowej ${ }^{2}$.

W grudniu 1683 roku nadworny marszałek koronny Hieronim August Lubomirski wraz ze swą siostrą wojewodziną Krystyną Potocką ofiarowal kapucynom tzw. pałac Spiski, położony na rynku. W dniu 20 stycznia 1684 roku bp Jan Małachowski ${ }^{3}$ wyraził zgodę na stały pobyt kapucynów w Krakowie. Fundacji tej kapucyni nie przyjęli. Dla kierujących się przede wszystkim prawem ubóstwa zakonników kamienica w rynku była zbyt okazałą fundacją. Zgodnie $\mathrm{z}$ zakonnym zwyczajem kapucyni pragnęli posiadać klasztor poza murami miejskimi. Na skutek odmowy przyjęcia kamienicy Lubomirscy wykupili darowiznę, przekazując pieniądze na budowę klasztoru w innym miejscu.

Po zakończeniu głównych prac przy budowie konwentu warszawskiego przystąpiono do budowy klasztoru w Krakowie. W 1694 roku, wraz z dwoma towarzyszami: o. Bernardynem Ragnonim ${ }^{4}$ i br. Karolem Benedettim ${ }^{5}$ przybył do Krakowa o. Franciszek Marchi - późniejszy komisarz generalny. W drodze zatrzymali się na krótko w Kielcach, gdzie rezydowal bp Małachowski, by potwierdzić prawo pobytu i budowy klasztoru w Krakowie. W roku następnym, w dniu 4 sierpnia, kapucyni przybyli do Krakowa już na stały pobyt i zatrzymali się w domu pochodzącego z Wloch kupca Dionizego Mecottiego. W kilka dni później, z polecenia biskupa Stanisława Szembeka ${ }^{6}$ zamieszkali przy drewnianym kościele pod wezwaniem Św. Piotra na Garbarach ${ }^{7}$. W dniu 4 października 1695 roku, w uroczystość św. Franciszka, zamieszkali w tymczasowym hospicjum

${ }^{2}$ KKZ, s. 2-3. - SPK I, s. 84; J. Marecki, Kościỏl i klasztor Kapucynów w Krakowie. Przewodnik. Kraków 1995, s. 5.

${ }^{3}$ Jan Małachowski (1623-1699) pełnił wiele funkcji państwowych (m.in. referendarz koronny) i kościelnych (m.in. kanonik krakowski i warszawski, opat komendatoryjny w Mogilnie, kilkakrolny proboszcz). Od 1676 biskup chełmiński, a od 1861 krakowski. Por. P. Nitecki, Biskupi Kościola w Polsce. Warszawa 1992, s. 135.

${ }^{4}$ O. Bernardyn, Laktancjusz Ragnoni (1633-1742) do prowincji toskańskich kapucynów wstapil w 1681. Kaznodzieja, gwardian, sekretarz prowincjała. W latach 1694-99 przebywal w polskich klaszlorach. - SPK II, s. 210.

${ }^{5} \mathrm{Br}$. Karol, Jan Benedetti (1669-1735), do prowincji toskańskiej wstąpił w 1689. Zajmował się wyrobem sukna. W latach 1695-99 pracował w Polsce. SPK I, s. 282.

- Stanisław Szembek (1650-1721), duszpasterz, polityk, obrońca praw Kościoła. Zajmował różne stanowiska kościelne, do 1690 sulragan krakowski, do 1700 ordynariusz kujawsko-pomorski, od 1706 metropolita gnieźnieński. P. Nitecki, Biskupi..., s. 201.

${ }^{7}$ Kościół pw. Sw. Piotra usytuowany był przy dzisiejszej ul. Lobzowskiej i pełnil role świątyni parafialnej dla przedmieścia Garbary. Por. J. Marecki, Kościól..., s. 6. 
z kaplica, wybudowanym na placu przyszlego konwentu. Wykupiono od karmelitów trzewiczkowych i włoskich właścicieli ogrody - niegdyś koryto Wisly a potem Rudawy - leżące okolo 200 metrów od murów miejskich w pobliżu kościoła Św. Anny. Cały plac kosztowal około 9360 złp. W oparciu o darowizny Wojciecha Dembińskiego, Franciszka Wielopolskiego, Staszowskich, Stanisława Warszyckiego i innych dobrodziejów przystąpiono wiosną 1696 roku do budowy klasztoru i kościoła, którą ukończono w trzy lata później ${ }^{8}$.

Plany klasztoru i kościoła wykonał warszawski architekt Jan Ceroni a poświęcenia kamienia węgielnego dokonal w dniu $10 \mathrm{kwietnia} 1696 \mathrm{roku}$ bp Jan Małachowski. Prace budowlane, prowadzone wpierw pod kierunkiem architekta Ceroniego a potem Marcina Pellegriniego, zakończono w 1699 roku. We wrześniu tego roku zamieszkało w klasztorze 13 zakonników. Uroczyste przekazanie kluczy kapucynom przez głównego benefaktora nastąpiło 3 października 1699 roku. Wtedy to Dembiński przekazał kościół i klasztor na wieczystą własność kapucynom. W dniu 15 sierpnia 1700 roku odprawiono w kościele pierwszą Mszę św. Konsekracja kościoła miała miejsce 13 maja 1703 roku. Dokonał jej sufragan krakowski, bp Kazimierz Lubieński ${ }^{9}$.

Fundatorką trzeciego $\mathrm{z}$ kolei klasztoru kapucynów na ziemiach polskich była księżna Elżbieta z Lubomirskich Sieniawska. W 1708 roku zakupiła dla kapucynów od rajcy lwowskiego Franciszka Obrockiego za 1000 talarów plac oraz dom na Przedmieściu Halickim i przekazała je zakonowi. W następnym roku po otrzymaniu od zarządu generalnego zakonu pozwolenia na osiedlenie się we Lwowie rozpoczęto budowę konwentu według planów architekta Giovanniego Spazzio. W 1715 roku kanonicznie erygowano dom zakonny. W dniu 21 V 1718 roku abp Jan Skarbek ${ }^{10}$ konsekrowal świątynię klasztorną pw. Niepokalanego Poczęcia XMP ${ }^{11}$.

W klasztorze przez pewien czas istnial nowicjat (1723 - 1733), od 1739 ro:u sudium filozoficzne a potem teologiczne. Klasztor słynął z zasobnej bibloteki $i$ dziel sztuki. Między innymi w konwencie znajdowały się

- J. Marecki, Kościól..., s. 6-8.

- SPK I, s. 162.

* Jas Srarbek (1661-1733), od 1696 sufragan lwowski, a od 1713 lamże metropolita. Deai a dusoplinẹ duchowieństwa i rozwojj budownictwa sakralnego. P. Nitecki, Biskupi..., s is

- AZ Preybycie OO. Kapucynów na Zamarstynów, ks. 1. - AKZ 7, s. 4. - SPK I, s. $126-10$

$=0$. Francizzek, Jan Piotr Marchi (1672-1719) do prowincji toskańskiej kapucynów - Eupazi i6- Od 1692 pracowal w polskich klasztorach. Kaznodzieja, gwardian i komisarz sorata zołon * Polsce. Pozostawił po sobie kilka rzeźb. Zmarł w opinii świętości we Loowx podcas piekęgnowania chorych na zarazę. - SPK II, s. 46. 
obrazy Jerzego Eleutera Siemiginowskiego, Martina Altomontiego, Franciszka Ecksteina i rzeźby o. Franciszka Marchiego ${ }^{12}$. Głównymi dobrodziejami kapucynów lwowskich były rody Sieniawskich i Rzewuskich. Oni to ofiarowali konwentowi swoje księgozbiory i obrazy ${ }^{13}$.

Konwent był ośrodkiem misyjnym dla kapucynów różnych narodowości, udających się na wschód. Znany byl także jako ośrodek myśli katolickiej i teologicznej. Słynni kaznodzieje kapucyńscy swymi kazaniami przyciągali słuchaczy. Sympatię zyskali jednak pelnym poświęcenia pielęgnowaniem chorych na Przedmieściu Łyczakowskim podczas ,morowego powietrza" w 1719 roku. O. Józef Maniewski ${ }^{14}$ i o. Franciszek Marchi zaraziwszy się od chorych zmarli po kilku tygodniach. Mieszkańcy Lwowa uważali zmarłych zakonników za ,świętych”. Ich pogrzeby stały się manifestacjami religijnymi ${ }^{15}$.

W lipcu 1785 roku decyzją władz gubernium postanowiono zlikwidować klasztor kapucynów. Wierni broniący konwentu rozeszli się z płaczem do domów dopiero na wyraźne żądanie abpa Ferdynanda Kickiego ${ }^{16}$, stojącego po stronie gubernium. Po 77 latach pobytu we Lwowie kapucyni zostali zmuszeni do opuszczenia swego klasztoru. $Z$ polecenia władz austriackich klasztor przejęli franciszkanie konwentualni a księgozbiór włączono do Biblioteki Uniwersyteckiej ${ }^{17}$.

- Tak zakończyła „swój żywot” trzecia z kolei fundacja kapucyńska na ziemiach polskich, z którą wiązano wiele planów na przyszłość.

\section{KAPUCYNI WE LWOWIE-ZAMARSTYNOWIE}

Po raz drugi próbę osiedlenia się we Lwowie, po 119 latach, podjẹli kapucyni w 1904 roku. Po 42 latach pracy duszpasterskiej "na lwowskim Zamarstynowie", po wybudowaniu nowego kościoła i klasztoru, zostali zmuszeni kolejny już raz - i jak poprzednio nie wlasną decyzją - do

13 SPK I, s. 187

14 O. Józef, Mateusz Maniewski (1687-1719), do zakonu wstąpił w 1713. Oddawał się pracy kaznodziejskiej. Zmarł podczas pełnienia posług duszpasterskich przy chorych na zaraze. - SPK II, s. 41.

15 SPK I, s. 187.

${ }^{16}$ Ferdynand Kicki (1720-1797), oficer a potem duszpasterz, działacz polityczny, zwolennik reform józefińskich. Od 1777 sufragan, a od 1780 metropolita lwowski. P. Nitecki, Biskupi.... s. 101.

${ }_{17}$ AZ, Przybycie OO. Kapucynów na Zamarstynów, rkp., ks. 1. - AKZ 7, s. 5; Archiwum klasztoru kapucynów w Sędziszowie Małop. sygn. 34, Historia Conventus. Tomus secundus, s. 1-2; Archiwum klasztoru kapucynów w Kutkorzu sygn. 3, Annales Conventus Kutkoriensis, s. 6-7, 15. - SPK I, s. 187. 
opuszczenia miasta. „Repatriacja”, która w rzeczywistości byla „deportacją" pozbawila ich, podobnie jak i innych prawowitych mieszkańców wschodnich województw Rzeczypospolitej, prawa pobytu i własności.

Poniżej przedstawiono dzieje kapucynów we Lwowie-Zamarstynowie, zestawiając najważniejsze wydarzenia dotyczące konwentu i duszpasterskiej dzialalności, ujmując je w kalendarium. Przeprowadzono kwerendę w czterech archiwach, w których znajdują się podstawowe materiały dotyczące pobytu kapucynów we Lwowie-Zamarstynowie: Archiwum Kurii Generalnej Zakonu Kapucynów w Rzymie, Archiwum Kurii Metropolitalnej we Lwowie - depozyt w Lubaczowie, Archiwum Prowincji Krakowskiej Kapucynów w Krakowie i Archiwum Klasztoru Kapucynów we Lwowie-Zamarstynowie (zdeponowanym od 1946 r. w Archiwum Prowincji Krakowskiej Kapucynów w Krakowie).

W Archiwum Kurii Generalnej (AGO) pod sygnaturą G. 49 w sekcji drugiej znajdują się powizytacyjne wskazania i relacje odnośnie do „stanu moralnego" komisariatu krakowskiego, w piątej - o wspólnym tytule Conventus zgromadzono korespondencję, odpisy i kopie dokumentów oraz sprawozdania dotycżące klasztoru zamarstynowskiego. Sekcja szósta zawiera korespondencję dotyczącą zarządzania prowincją krakowską. W sekcji trzeciej (Epistolae) i dziewiątej (Scriptores) zachowały się dokumenty odnoszące się do omawianego konwentu i zakonników tam przebywając.ch. Uchwały $\mathrm{z}$ posiedzeń zarządu generalnego zakonu (KGZ) z okresu miẹdzywojennego znajdują się w zbiorze sygnowanym AH 12.

Iv Archiwum Kurii Metropolitalnej obrządku lacińskiego we Lwowie (Ad). które znajduje się w Lubaczowie, zachowały się dokumenty kanxlaryjne „Księgi indeksowe” (sygn. 105, 107, 109, 1050 1052, 1057), $z$ kiónch można odtworzyć nazwy dokumentów i daty ich sporządzenia - 2w kzzeza utedy, gdy oryginały i odpisy zaginęly. Notowano w nich - seikie dokumenty i korespondencję Kurii Metropolitalnej, dodając częso transumpty lub ich streszczenia. Są to cenne źródła, zwlaszcza do lat ax upaci z terenu metropolii lwowskiej, z którego to czasu (1939-1945) moto się oryginały dokumentów. Wspomniane Archiwum posiada zicze czaty. .Archiwa Parafialne", wśród których znajduje się teczka Zemers:nów" i dzial „Polski Komitet Opieki”, w którym przechowywa- ma:erialy dotvczące kuchni zorganizowanej przez o. Bogumiła Maredies: Ten ostatni dokument zawiera - odnośnie do kuchni prowadzo- sapucyón - niekompletne rachunki, karty zapotrzebowania : Jiescone sprauozdania. Wydaje się, że zasób „Parafia Zamarstynów” acos ackompletowany. Wiele akt, na które natrafiono w tym dziale

- O Dogarer Mradysła Marecki (1907-1974), do zakonu wstąpił w 1928, kapł. 1936. C motosece przeloziony. Z zamilowania gralik i jubiler. - SPK II, s. 47-48. 
podczas kwerendy, ma swoje koncepty i kopie w zbiorach Archiwum Klasztoru Kapucynów we Lwowie-Zamarstynowie.

Archiwum Prowincji Krakowskiej Kapucynów w Krakowie (AP) posiada akta i noty dotyczące konwentu zamarstynowskiego z lat 1904-1946. Dokumenty zebrane są w kilku zbiorach. Najważniejsze z nich to: „Rozporządzenie Konstystorza lwowskiego. 1782-1937' (sygn. 5, k. 109-353) - cytowane ACC, ACP, akta posiedzeń zarządu komisariatu i prowincjałatu (sygn. 10b, 10c), „Księga kasowa Prowincji. 1921-1932” (sygn. 16), „Akta klasztoru OO. Kapucynów w Zamarstynowie. Dokumenty. Korespondencja. Inwentarze. Plany. 1903-1943” (sygn. 24) - cytowane AZ oraz „Kronika Prowincji Krakowskiej OO. Kapucynów, t. 2" (1921-1973) (sygn. 45) - cytowana KPK. Dział personalny Archiwum Prowincji (APZ) posiada także cenne materiały do poznania działalności i życia klasztoru zamarstynowskiego. Wystarczy chociażby wymienić wspomnienia i relacje br. Efrema Chmiela ${ }^{19}$, o. Tytusa Gorczycy ${ }^{20}$, o. Floriana Nestorowskiego ${ }^{21}$, o. Romualda Szczałby ${ }^{22}$ i o. Hieronima Warachima ${ }^{23}$.

Najcenniejszy dla historyka jest zbiór akt zachowany w Archiwum Klasztoru Kapucynów we Lwowie-Zamarstynowie (AKZ), który po deportacji zakonników ze Lwowa w 1946 roku zostal zdeponowany w Archiwum Prowincji Krakowskiej Kapucynów w Krakowie. Należy zaznaczyć, że zachowalo się całe archiwum domowe (klasztorne); brak natomiast niektórych ksiąg metrykalnych $\mathrm{z}$ archiwum parafialnego. Ze względów praktycznych księgi urzędu parafialnego przechowuje się w depozycie razem $\mathrm{z}$ archiwum klasztoru zamarstynowskiego. Są jednak zbiorem uydzielonym i nie posiadają sygnatur archiwum kapucyńskiego.

Przy opracowaniu poniższego kalendarium oparto się na nastepugacych jednostkach archiwalnych, pochodzących z klasztoru zamarsxymowskiego: „Spis aktów klasztornych" [1900-1924] (sygn. 5). .Ksigen rouporządzeń. 1910-1942” (sygn. 6), „Kronika klasztoru OO. KapaciLwów na Zamarstynowie. Od roku pańskiego 1904 [do 1939 (sin 7 - cytowana KKZ, „Dom Parafialny [1932-1935]” (sven. 8) Dat Bezprocentowej Kasy Pożyczkowej przy parafii pw.

19 APZ sygn. 54; E. Chmiel, Kronika prowincji drakouxbig al r. MS5 (do MS4); Tenze, Pamiętnik uchodźca [1939-1940]; Tenże, Życiorys i rabued Talace Srouidawa Chmiela.

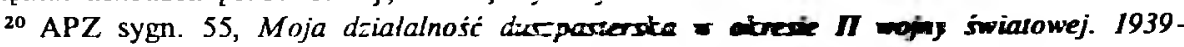
-1945. Mps, Kraków, [brw].

21 APZ sygn. 72, F. Nestoroushi, Manograja tialadnaici o. Foriana Nestorowskiego kapucyna. Mps.

22 APZ brak sygn., R. Szczaba, Moja podrö̇ [1939]; Tenże, Opuszczamy Lwów. Kraków 1986.

23 APZ brak sygn., H. Warachim, Kapucyni we Lwowie (w 40-ta rocznice opuszczenia klasztoru). Mps, Wiener Neustadt 1986; Tenże, O. Aleksander Chmura. Gdańsk 1979. 
ża (OO. Kapucyni)” (sygn. 9). Sygnatur nie posiadają zbiory: „Księga III Zakonu św. Franciszka [w Zamarstynowie]”, „Misje ludowe i rekolekcje”, „Korespondencja z Kurią Metropolitalną obrz. lac. we Lwowie”, „Spis aparatów kościelnych przywiezionych ze Lwowa, Kraków, 23 VI 1946".

Wymienione archiwalia należy uzupełnić $w$ przyszłości dokumentami znajdującymi się we lwowskim archiwum miejskim i wojewódzkim. Obecnie dostęp do nich jest niemoźliwy.

Przedstawiona $w$ postaci kalendarium historia klasztoru kapucynów i prowadzonej przez nich parafii pw. św. Franciszka z Asyżu we Lwowie-Zamarstynowie przyczyni się do lepszego poznania roli, jaką odegrali kapucyni w I. poł. XX wieku na terenie archidiecezji lwowskiej. Tak ujęta historia pozwala badaczowi przeszłości na wyciąganie indywidualnych wniosków i formowanie wlasnych sądów. Tym samym jest zachętą do dalszych badań i opracowań monograficznych. Równocześnie jest wyrazem wdzięczności za trud życia zakonnego i działalność duszpasterską dla osób, które zostały w niniejszym opracowaniu wymienione.

\section{KALENDARIUM}

\section{XI/XII 1903}

Matka M. Morawska ${ }^{24}$ - przełożona Sióstr od Wieczystej Adoracji Najśw. Sakramentu podjęła starania o sprowadzenie do Lwowa kapucynów dla opieki duszpasterskiej nad siostrami. Abp Józef Bilczewski ${ }^{25}$ wyraził zgodę na osiedlenie sie kapucynów i wybudowanie kościoła $w$ wydzielonym $z$ parafii pw. św. Marcina osiedlu Zamarstynów ${ }^{26}$.

\section{1904}

Spotkanie zarządu prowincji z abp. Józefem Bilczewskim, na którym to spotkaniu ustalono, że kapucyni osiedlą się w Zamarstynowie ${ }^{27}$.

24 Ludwika Nałęcz-Morawska (1843-1906), w Zakonie Mniszek Klarysek od Wieczystej Adoracj - nazywanych popularnie Klaryskami od Wieczystej Adoracji - s. Maria od Krzyża. Twórczyni polskiej gałęzi zakonu. Założyła pierwszy klasztor w Granowie k. Pomnania, potem w Gnieźnie, a od 1873 we Lwowie przy ul. Kurkowej. Tam też pochowana.

H. Kolak, J. Marecki, Leksykon godel zakonów. Lódź 1994, s. 136.

2: Józef Bilczewski (1860-1923), biblista i dogmatyk, profesor i rektor Uniwersytetu Lwowskiego (1900), działacz społeczny, duszpasterz. Od 1900 metropolita lwowski. P Nitedi, Biskupi..., s. 30 .

* AZ, List bpa J. Webera do prow. I. Kolbusza, Lwów 11 XII 1903, k. 4-4v. - KKZ, s.

2* AZ, Pr=ybycie..., k. 1. - KKZ, s. 7-8. 


\section{II 1904}

Sesja defnitorialna pod przewodnictwem prowincjała o. Ignacego Kolbusza ${ }^{28}$ w Sędziszowie Młp., na której jednogłośnie zdecydowano o osiedleniu się kapucynów w Zamarstynowie pod Lwowem oraz wybudowaniu klasztoru i przyjęciu parafii ${ }^{29}$.

\section{IV 1904}

Generał Zakonu, o. Bernard $\mathrm{z}$ Andermatt ${ }^{30}$, wyraził zgodę na otwarcie domu zakonnego w Zamarstynowie k. Lwowa ${ }^{31}$.

\section{$19 \vee 1904$}

Oddanie kapucynom przez proboszcza ks. Edwarda Podolskiego ${ }^{32}$ parceli, należącej do parafii pw. Św. Marcina, pod klasztor i kościól parafialny ${ }^{33}$.

\section{VI 1904}

Gwardian z Kutkorza, o. Rudolf Ficowski ${ }^{34}$, poświęcił kamień węgielny pod budowę ,tymczasowego" domu zakonnego w Zamarstynowie ${ }^{35}$.

28 O. Ignacy, Jan Kolbusz (1852-1916), do zakonu kapucynów wsląpił 1870, a w sześć lat póżniej otrzymał święcenia kapłańskie. Kaznodzieja i misjonarz ludowy, gwardian, definitor, prowincjał. - SPK I, s. 583.

29 AZ. Przybycie..., k. lv; Tamże, Protokól ze zgromadzenia przewielehnych ojców exprowincjalów $i$ definitora pod przewodnictwem przewielebnego ojca prowincjala Ignacego w sprawie przyjecia klasztoru i parafii we Lwowie, k. 13-13v. - KKZ, s. 9.

${ }^{30}$ O. Bernard Christen (1837-1909). Do szwajcarskiej prowincji kapucynów wstąpił w 1855. W życiu zakonnym petnił różne obowiązki, m.in. profesora seminarium, magistra nowicjatu, prowincjała. W latach 1884-1908 generał zakonu, od 1908 biskup tytularny Stauropolitany. LC k. 400.

31 AZ, Przybycie..., k. 1v. - KKZ, s. 10.

32 Ks. Edward Podolski $(+1910)$, kapłan arch. Iwowskiej, proboszcz parafii pw. św. Marcina we Lwowie do 1910 roku. Relacja ustna o. R. Szczałby. Kraków, 25 IV 1996.

33 AZ, Przybycie..., k. 1. - KKZ, s. 10

34 O. Rudolf, Wladysław Ficowski (ur. 1865), do zakonu wstąpił 1885, kapł. 1890, a w 1910 otrzymał dekret inkardynujący go do arch. Iwowskiej. Katecheta, spowiednik, kaznodzieja, gwardian. SPK I, s. 414.

$35 \mathrm{AZ}, \operatorname{Przybycie...,~k.~lv.~-~KKZ,~s.~} 11$. 


\section{VI 1904}

Poświęcenie przez wikariusza prowincji, o. Bronisława Stępka ${ }^{36}$, kamienia węgielnego pod budowę, pod kierunkiem Zygmunta Krykiewicza ${ }^{37}$, tymczasowej kaplicy ${ }^{38}$.

\section{VII 1904}

Kongregacja definitorialna w Krośnie, na której ustalono obsadę klasztoru w Zamarstynowie ${ }^{39}$. Pierwszym przełożonym kapucynów w Zamarstynowie zostal wikariusz prowincjalny o. Bronisław Stępek oraz o. Kajetan Rusin $^{40}$, o. Anioł Madejewski ${ }^{41}$ i br. Dydak Dziobek ${ }^{42}$.

\section{VII 1904}

Uroczyste poświęcenie i wprowadzenie kapucynów do kaplicy ${ }^{43}$.

\section{VIII 1904}

O. Bronisław Stępek został przez Konsystorz Metropolitalny we Lwowie mianowany kooperatorem przy kościele pw. Św. Marcina we Lwowie ${ }^{44}$.

36 O. Bronisław, Jan Stępek (1855-1925, do zakonu wstąpił w 1875, kapł. 1878. Katecheta, wielokrotny wikary i gwardian, proboszcz, misjonarz ludowy. - SPK II, s. $312 \cdot 313$.

${ }^{37}$ Zygmunt Krykiewicz ( + przed 1937), inż. budowlany, zam. we Lwowie. Relacja ustna o. R. Szczałby (Kraków, 25 IV 1996).

$30 \mathrm{KKZ}$, s. 11 .

39 ACC, Krosno 19 VI 1904, s. 150. - AZ, Przybycie..., k. 1v. - KKZ, s. 12-13.

* O. Kajetan, Ludwik Rusin (ur. 1896), do zakonu wstapił w 1885, kapł. 1890. Spowiednik, kaznodzieja, magister nowicjatu, gwardian, proboszcz i definitor. Po otrzymaniu dekretu sekularyzacyjnego (1909) pracowal w duszpasterstwie polonijnym w USA. - SPK II, s. 237 .

4: O. Anioł, Kazimierz Władysław Madejewski (1873-1951), do zakonu wstąpił 1895, kapi 1898. Spowiednik, katecheta, ojciec duchowny, rekolekcjonista i kaznodzieja, działacz podezo-patriotyczny. - SPK II, s. 18-20.

- Br. Dydak, Jan Dzjobek (ur. 1896), do galicyjskiej prowincji kapucynów wstąpił - 18 Suby nieczyste złożył w 1900. Pełnił obowiązki kucharza i zakrystiana. W okresie I ogry swiatowej w armii austriackiej. W 1921 otrzymal zwolnienie ze ślubów zakonnych. - SPK 1. s 404.

AZ AZ, Prabycie... k. 2. - KPK, s. 9. - KKZ, s. 12-13; Fotografia kaplicy. W: Ped ajous dozona przez ks. Aniola [Madejewskiegol gwardiana OO. Kapucynów w kośace Zumartynowie. Lwów [1904], s. 1.

* AZ Lisa abpa J. Webera do prow. o. I. Kolbusza (Lwów, 10 VIII 1904), k. 8. 


\section{VIII 1904}

Przełożony hospicjum, o. Bronisław Stępek, zostal przez Konsystorz Metropolialny we Lwowie zamianowany ekspozytem dla ekspozytury ,Zamarstynów" wydzielonej z parafii pw. Św. Marcina ${ }^{45}$.

\section{VIII 1904}

Przekazanie kapucynom przez proboszcza parafii pw. Św. Marcina w opiekę duszpasterską wiosek Hołosko Wielkie i Hołosko Małe ${ }^{46}$.

\section{VIII 1904}

Konsystorz lwowski wydal decyzję uznającą kościól pw. Św. Franciszka z Asyżu, obsługiwany przez kapucynów za kościól fiflialny parafii pw. Św. Marcina oraz polecil, by wydać eskpozyturze stosowne księgi parafialne. Zatwierdzil ponadto pieczęć ekspozytury ${ }^{47}$.

\section{XII 1904}

Abp Józef Bilczewski zezwolił kapucynom na założenie domu zakonnego w Zamarstynowie ${ }^{48}$.

\section{II 1905}

Kanoniczna erekcja domu zakonnego kapucynów w Zamarstynowie ${ }^{49}$.

\section{VI 1906}

Zmiana w obsadzie domu zakonnego ${ }^{50}$ : o. Kajetana Rusina zastąpił o. Rafal Baran ${ }^{51}$.

$45 \mathrm{KKZ}$, s. 14.

46 Tamże, s. 14.

47 Tamże, s. $14-16$.

48 AZ, List abpa J. Webera do prow. o. I. Kolbusza. Lwów, 10 VIII 1904, k. 9. - KKZ, s. 17 .

49 AZ, Akt kanonicznej erekcji domu zakonnego w Zamarstynowie przez St. Apostolską. Rzym, 11 III 1905, k. 11; Tamże, Dokument generala zakonu o. Bernarda z Andermat dotyczący erekcji klasztoru w Zamarstynowie. Rzym, 17 ll 1905, k. 12. - KKZ, s. 18-19.

50 ACC, Sẹdziszów, 19 VI 1906, k. 153.

s1 O. Roman, Tomasz Baran (1877-1913), do zakonu kapucynów wstąpił w 1897, kapł. 1904. Do śmierci pracował jako katecheta w Zamarstynowie. SPK I, s. 267. 


\section{III 1908}

Wprowadzenie Bractwa Szkaplerza św. Józefa ${ }^{52}$ przy kościele kapucynów ${ }^{53}$.

\section{VI 1908}

Poświęcenie sztandaru, ufundowanego znacznym nakładem katechety o. Rafała Barana, dla szkoły powszechnej w Zamarstynowie ${ }^{54}$.

\section{1-15 VII 1908}

Wizytacja kanoniczna konwentu, przeprowadzona przez o. Augustyna Watrasa ${ }^{55}$, prowincjala ${ }^{56}$.

\section{VII 1908}

Żona dyrektora szkoły im. Św. Anny w Krakowie, Julia Grossowa ${ }^{57}$, ofiarowała kapucyrom w Zamarstynowie m.in. 6 lichtarzy $i$ świece, a w miesiąc później tabernakulum ${ }^{58}$.

\section{5-27 VIII 1908}

Definitor generalny, o. Benno Auracher ${ }^{59}$, w towarzystwie prowincjała o. Augustyna Watrasa wizytowal hospicjum kapucynów w Zamarstynowie ${ }^{60}$.

32 Bractwo szkaplerza św. Józefa propagował w Galicji o. Florian Janocha (1855-1921). Pod jego wpływem w parafii zamarstynowskiej szerzył się ów kult. - SPK I, s. 511-512; Relacja ustna o. R. Szczalby (Kraków 25 IV 1996).

$\$ 3 \mathrm{KKZ}$, s. 26.

s* Tamże, s. 28.

s: O. Augustyn, Michał Watras (1860-1921), do galicyjskiej prowincji kapucynów wstaFe 1881, kapł. 1885. Kaznodzieja, gwardian, delinitor, prowincjał. - SPK II, s. 399-400.

* KKZ, s. $29-30$.

5 Jilia Grossow'a (+ przed 1939), krewna o. Anioła Madejewskiego. Relacja usina = Szzaze (krakow, 25 IV 1996).

- KKZ s. 30.

- O Banno-Gotgardus Auracher (1872-1951), alumn prowincji bawarskiej, do zakonu

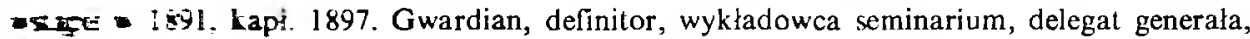
dencer atach 1908-1914. - Por. „Analecta Ordinis Fratrum Minorum CapucIntrim- T $6^{-}$(1951), s. 287-290. - LC, 322.

- AG. Ifs G. 49, sec. 2, dekrel powizytacyjny o. Benno a Monachium dla prowincji painzsiog (Kriow; 8 IX 1908, s. 6). - KKZ, s. 31. 


\section{IX 1908}

Uroczysta Msza św. w intencji zamarstynowskiej Rady Gminnej, którą odprawił przełożony klasztoru o. Bronisław Stępek - czlonek tejże Rady ${ }^{61}$.

\section{$13 \times 1908$}

Rozpoczęcie katechizacji w nowo powstałej szkole w Holosku Małym ${ }^{62}$.

\section{XI 1908}

Uroczyste obchody 50-lecia kapłaństwa Piusa $X^{63}$ w kościele kapucynów i w szkołach na terenie gminy Zamarstynów ${ }^{64}$.

\section{II 1909}

Z polecenia Konsystorza Metropolitalnego kapucyni rozpoczęli w Wiedniu starania o ustanowienie samodzielnej ekspozytury na terenie gminy Zamarstynów ${ }^{65}$.

\section{II 1909}

Poświęcenie i ustawienie $w$ bocznym ołtarzu kaplicy figury św. Józefa, ofiarowanej przez dobrodziejów ${ }^{66}$.

\section{IV 1909}

J. Grossowa w Krakowa ofiarowala do kaplicy zamarstynowskiej figurę Najśw. Serca Pana Jezusa ${ }^{67}$.

\section{8-14 V 1909}

Wizytacja kanoniczna, której przewodniczył prowincjał, o. Augustyn Watras ${ }^{68}$.

$61 \mathrm{KKZ}$, s. 32.

62 Tamże, s. 35.

63 Giuseppe Sarto (1835-1914), teolog, duszpasterz, do 1884 bp Mantui, kardynał i patriarcha Wenecji. W 1903 wybrany papieżem przyjął imię Piusa X. Kanonizowany w 1954. - H. Stadler, Leksykon..., s. 259-261.

$64 \mathrm{KKZ}$, s. 37.

65 Tamże, s. 42.

66 Tamże, s. 42.

67 Tamże, s. 44.

68 Tamże, s. 45-46. 


\section{VII 1909}

Mianowanie przełożonym domu i ekspozytem o. Anioła Madejewskiego ${ }^{69}$.

\section{VII-XI 1909}

Wykonano nowy ołtarz z figurami św. Józefa i św. Antoniego oraz obraz „Porcjunkuli”; w bocznych ołtarzach ustawiono figury Serca Pana Jezusa i Serca Najśw. Maryi Panny. Przeprowadzono remont domu mieszkalnego ${ }^{70}$.

\section{XI 1909}

Po raz pierwszy zorganizowano procesję na cmentarz zamarstynowski. Zapoczątkowano praktykę „pierwszych piątków” ${ }^{11}$.

\section{XI 1909}

Opodatkowanie wszystkich klasztorów galicyjskiej prowincji kapucynów w wysokości 300 koron rocznie na rzecz budowy konwentu w Zamarstynowie ${ }^{72}$.

\section{I 1910}

$\mathrm{Na}$ miejsce $\mathrm{o}$. Bronislawa przybył $\mathrm{o}$. Antoni Latawiec ${ }^{73} \mathrm{z}$ klasztoru sędziszou'skiego ${ }^{74}$.

\section{1910}

Zakupiono fisharmonię do kaplicy ${ }^{75}$.

\section{$15 \vee 1910$}

Pożar kaplicy podczas Mszy św., spowodowany przez chłopców, którzy dla zabawy podpalili stojący $w$ pobliżu kaplicy pojemnik $z$ ropą ${ }^{76}$.

AZ, List o. A. Madejewskiego do prow. o. I. Kolbusza. Lwów 20 XI 1909, r. $17-17 v$.

○KZ, s. 50 .

${ }^{-1}$ Tamże, s. 52.

= List okólny prow. o. A. Watrasa. Sędziszów, 6 XI 1909, k. 238.

3 O. Antoni, Jan Latawiec (1881-1961), do zakonu wstąpił 1900, kapł. 1906. Pełnił - żciu zakonnym różne funkcje, m.in. prefekta kleryków, wicemagisıra nowicjuszy, gwardiana, dyrektora II Zakonu, katechety, wikarego klasztoru, dyrektora Kolegium Serafidikego. bibliotekarza. - SPK I, s. 665.

- KKZ, s. 53.

- Tamie.

Tamze, s. 54. 


\section{VI 1910}

Kanoniczna erekcja Drogi Krzyżowej w kaplicy eskpozytury, której dokonal o. Walerian Gawędziński ${ }^{77}$, reformata ze Lwowa ${ }^{78}$.

\section{VII 1910}

Uroczyste obchody 500-lecia bitwy pod Grunwaldem, organizowane przez kapucynów dla mieszkańców Zamarstynowa i okolicy. Msza św. polowa, poświęcenie pomnika-krzyża i defilada ${ }^{79}$.

\section{1910}

Objęcie katechezą szkoły ogrodniczej, powstałej na terenie ekspozytury Zamarstynów. Katechetą został o. Anioł Madejewski ${ }^{80}$.

\section{IX 1910}

Kapucyni otrzymali z Wiednia przez pośrednictwo C. K. Namiestnictwa we Lwowie pozwolenie na utworzenie samodzielnej ekspozytury duszpasterskiej $^{81}$.

\section{XII 1910}

Po raz pierwszy odprawiono w kaplicy ekspozytury pasterkę bożonarodzeniową ${ }^{82}$.

\section{1911}

Wystawienie przygotowanych przez o. Anioła Madejewskiego, katechetę szkolnego ,Jasełek”, z których dochód przeznaczono na budowę parafialnej Ochronki ${ }^{83}$.

77 O. Walerian Gawędziński (1863-1915), reformata, do zakonu wstąpił w 1888, święcenia kapłańskie otrzymał w 1894. Kaznodzieja, misjonarz ludowy, gwardian, magister nowicjalu, delinitor, redaktor „Poslańca św. Antoniego". - Archiwum Braci Mniejszych reformatów w Krakowie, Akta prowincjalskie... podczas urzędowania o. Z. Janickiego, 1914-1925 , s. 65 .

${ }^{78} \mathrm{KKZ}$, s. 55.

79 Tamże.

*o Tamże, s. 56.

81 AAL, Dział „Archiwa Parafialne”, Teczka „Zamarstynów”, Dokument C. K. Namiestnictwa zezwalający na utworzenie parafii w Zamarslynowie (Lwów, 16 VIII 1910), k.nlb. 9-10. - AP sygn. 5, Rozporządzenie Konstystorza Lwowskiego. List abpa J. Bilczewskiego do prow. o. A. Watrasa (Lwów, 7 XII 1912), k. 338. - KKZ, s. 56.

$82 \mathrm{KKZ}$, s. 57.

${ }^{83}$ Tamże, s. 58. 


\section{V 1911}

Uroczyste obchody święta Najświętszej Maryi Panny Królowej Polski, na które zlożyły się m.in. Msza św. polowa, okolicznościowe kazanie i pochód pod Krzyż Grunwaldzki ${ }^{84}$.

\section{I pot. VI 1911}

Wizytacja hospicjum, przeprowadzona przez prowincjała, o. Augustyna Watrasa ${ }^{85}$.

\section{VI 1911}

Ekspozytem w miejsce o. Anioła Madejskiego został mianowany o. Antoni Latawiec $^{86}$.

\section{VII-VIII 1911}

W okresie wakacyjnym kapucyni prowadzili posługę duszpasterską w sanatorium przeciwgruźlíczym w Hołosku Wielkim ${ }^{87}$.

\section{VII 1912}

Powołanie samodzielnej ekspozytury duszpasterskiej (niezależnie od parafii pw. św. Marcina) obsługiwanej przez kapucynów, obejmującej osiedle Zamarstynów - część lewobrzeżną, oraz wioski Hołosko Wielkie i Hołosko Make. Dokument ten dostarczono kapucynom dopiero 24 XII $1912^{88}$.

\section{VIII 1912}

Zmiana na stanowisku gwardiana i administratora parafii. O. Alfons Maria Wieczorek ${ }^{89}$ zastąpił o. Madejewskiego i o. Latawca ${ }^{90}$.

aKZ, s. 59.

as Tamże, s. 60 .

Tamie, s. 61 .

- Tamie.

- KZG, 29 IV 1927, KZG 20 V 1927. - AA] [bez sygn.], teczka „Zamarstynów”. Dotumenty dotyczące parafij pw. św. Franciszka, knlb. 7.

- O. Alfons Maria, Jan Wieczorek (1877-1936), do zakonu wstąpil w 1894, kapł. 1899. u șiu zakonnym petnił wiele funkcji: spowiednika, rekolekcjonisty i katechety, ojca duchow nego, katechety, wikarego, proboszcza, gwardiana i definitora. - SPK II, s. 411-412.

- ACC (Sęziszów, 9 VII 1912), s. 162. - AP sygn. 5, Rozporzadzenia..., Akt Nominaongy Konsystorza Meuropolitalnego Lwowskiego obrz. łac. na stanowisko administratora parzíi dla o. A. Wieczorka (Lwów, 17 VII 1912), k. 337. - AP sygn. 33, Akta personalne sowse. k. 125. - KKZ, s. 65. 


\section{1912}

O. Andrzej Kocyłowski ${ }^{91}$ został mianowany wikarym parafii pw. Sw. Marcina ${ }^{92}$.

\section{III 1913}

Zmarl o. Rafal Baran; zostal pogrzebany w nowo wybudowanym grobowcu zakonnym na cmentarzu zamarstynowskim ${ }^{93}$.

\section{9-22 V 1913}

Komisarz, o. Konstanty Jaroń ${ }^{94}$, przeprowadził wizytację kanoniczną domu zakonnego ${ }^{95}$.

\section{IX 1913}

$\mathrm{Na}$ miejsce zmarlego katechety, o. Rafała Barana, Konsystorz mianowal za zgodq wladz zakonnych o. Antoniego Latawca ${ }^{96}$.

\section{XII 1913}

Uroczyste obchody setnej rocznicy śmierci księcia Józefa Poniatowskiego w gminie Zamarstynów. Z tej okazji kapucyni odprawili w intencji Ojczyzny uroczystą Mszę św. z okolicznościowym kazaniem ${ }^{97}$.

\section{XII 1913}

Wizytacja klasztoru, przeprowadzona przez komisarza, o. Konstantyna Jaronia ${ }^{98}$.

91 O. Andrzej, Władysław Kocyłowski (ur. 1886), do zakonu wstąpił w 1902, kapł. 1910 a $w$ cztery lata później przeniesiony ad statum laicalem. W latach 20-tych powrócił na krótko do życia zakonnego w charakterze brata. - SPK I, s. 582-583.

$92 \mathrm{KKZ}$, s. 61.

93 AZ, List o. A. Wieczorka do kom. o. K. Jaronia (Lwów, 2 IV 1913), k. 29-30. - KKZ, s. $67-68$.

94 O. Konstanty, Władysław Jaroń (1873-1952), do galicyjskiej prowincji kapucynów wstąpił 1890, kapł. 1896. Spowieđnik, wikary konwentów, prefekt kleryków, gwardian, definitor, komisarz prowincjalny. Pisarz ascetyczny i rubrycysta. Bardzo popularny rekolekcjonista i misjonarz ludowy. - SPK I, s. 1518-1521.

95 AKZ sygn. 6, Ksiega rozporzadzeń, k. 15v. - KKZ, s. 75.

96 AP sygn. 5, Rozporządzenia Konsystorza Lwowskiego. 1782-1937. Nominacja Konsystorza Metropolitalnego obrz. łac. we Lwowie na stanowisko katechety dla o. A. Latawca (Lwów, 8 IX 1913), k. 343. - KKZ, s. 68.

${ }^{97} \mathrm{KKZ}$, s. 76.

98 Tamże. 


\section{VII 1914}

Rozpoczęcie remontu kaplicy pełniącej rolę świątyni parafialnej ${ }^{99}$.

\section{3-15 VII 1914}

Wizytacja kanoniczna klasztoru, którą przeprowadził komisarz, o. Konstanty Jaroń ${ }^{100}$.

\section{VIII 1914}

O. Anioł Madejewski w obawie przed represjami ze strony Rosjan za swą działalność patriotyczną opuścil Zamarstynów i wyjechal do Wiednia, gdzie opiekowal się m.in. polską emigracją lwowską. Powrócił 6 VIII $1915^{101}$.

\section{IX 1914}

Wojska rosyjskie wkroczyły do Lwowa i Zamarstynowa ${ }^{102}$.

\section{I pol. IV 1915}

Komisarz, o. Konstanty Jaroń, dokonal corocznej wizytacji domu zakonnego ${ }^{103}$.

\section{VI 1915}

Opuszczenie Lwowa i okolicy przez armię rosyjską, wypartą przez wojska austriackie ${ }^{104}$.

\section{1915}

Epidemia cholery w Zamarstynowie i okolicy. W kaplicy ekspozytury prowadzono codzienne modlitwy $z$ wystawieniem Najśw. Sakramentu i nabożeństu'o różańcowe o ustanie epidemii ${ }^{105}$.

- KKZ, s. 81.

AKZ sygn. 6, Ksiega..., k. 17v. - KKZ, s. 79.

45 KK, s. 102. - J. Marecki, Dzieje krakowskiej prowincji kapucynów w okresie II -ojmy intatowej (1939-1945) (Mps w posiadaniu AP), Kraków 1992, s. 113.

- KKZ s. 93.

Tamie, s. 102.

in Tamie, s. 100.

NkZ s 104 . 


\section{VIII 1915}

Wraz ze lwowianami, którzy opuścili miasto w obawie przed Rosjanami, powrócil z Wiednia - po roku - do klasztoru zamarstynowskiego o. Aniol Madejewski ${ }^{106}$.

\section{VIII 1916}

Wizytacja kanoniczna klasztoru, przeprowadzona przez komisarza, o. Konstantego Jaronia ${ }^{107}$.

\section{IV 1918}

Coroczna wizytacja kanoniczna przeprowadzona przez komisarza, o. Konstantego Jaronia ${ }^{108}$.

\section{VI 1918}

Uroczyste obchody w parafii zamarstynowskiej setnej rocznicy śmierci gen. Jana Henryka Dąbrowskiego, zorganizowane przy współudziale środowisk niepodległościowych ${ }^{109}$.

\section{$29 \times 1918$}

Administratorem parafii i przełożonym klasztoru został mianowany o. Czesław Szuber ${ }^{110} \mathrm{w}$ miejsce o. Alfonsa Wieczorka ${ }^{111}$.

\section{1-22 XI 1918}

Walki z nacjonalistami ukraińskimi na terenie Zamarstynowa i w okolicy. Oddział samoobrony zlożony z mieszkańców Zamarstynowa bronil skutecznie terenu gminy (tzw. odcinka Klaparów - Zamarstynów) przed bojówkami nacjonalistów ukraińskich ${ }^{112}$.

106 J. Marecki, Dzieje..., s. 113.

$107 \mathrm{KKz}$ sygn. 6, Ksiega..., k. 18. - KKZ, s. 123.

$108 \mathrm{KKZ}$, s. 139.

${ }^{109} \mathrm{KKZ}$, s. 143.

110 O. Czesław, Jan Szuber (1880-1951), do zakonu wstąpił w 1896, kapł. 1903. Dyrektor kleryków, opiekun II Zakonu, kaznodzieja i rekolekcjonista, wikary, gwardian, delinitor i czterokrotny przełożony komisariatu. Ze względu na zasługi częsıo nazywany pater provinciae. - SPK II, s. 33-336.

${ }^{111} \mathrm{KKZ}$, s. 147.

112 Tamże, s. 147-148; Semper fidelis. Obrona Lwowa w obrazach wspólczesnych. Lwów 1930 , s. 181 . 


\section{2 [14?] XI 1918}

Rusini zamordowali 12 mieszkańców Zamarstynowa. Podczas napadu uszkodzono kaplicę, wybito szyby i zniszczono figurę Najśw. Serca Pana Jezusa ${ }^{113}$.

\section{I/II 1919}

Przy klasztorze kapucynów zorganizowano Książęco-Biskupi Komitet ${ }^{114}$, który zajmował się m.in. rozdzielaniem żywności przesyłanej z Wielkopolski ${ }^{115}$.

\section{XI 1918-29 IV 1919}

Oblężenie Lwowa (i Zamarstynowa) przez bojówki Rusinów ${ }^{116}$.

\section{1919}

Odwiedzili kapucynów i zwiedzili kaplicę oraz ich klasztor abp Józef Bilczewski i sufragan bp Bolesław Twardowski ${ }^{117}$, ofiarując tysiąc koron na utrzymanie zakonników ${ }^{118}$.

\section{VIII 1919}

Kanoniczna wizytacja konwentu, którą przeprowadził komisarz, o. Konstanty Jaroń ${ }^{119}$.

\section{VII/VIII 1920}

W klasztorze zatrzymał się, uciekając przed Rosjanami, o. Marceli Surman ${ }^{120}$, gwardian z Kutkorza, udający się z inwentarzem klasztornym do Sędziszowa ${ }^{121}$.

$113 \mathrm{KKZ}$, s. 147.

114 Właściwie: Krakowski Biskupi Komitet Pomocy dla Dotkniętych Klęską Wojny, założony w V 1915, pracował do końca wojny, rozszerzając swą działalność na wszystkie ziemie polskie. - D. Olszewski, Polska chrześcijańska. Zarys dziejów (966-1984). Kielce 1985, s. 49-50; R. Bender, I wojna światowa i Polska niepodlegla. W: Chrześcijaństwo w Polsce. Zarys przemian 966-1945. Pod. red. J. Kłoczowskiego. Lublin 1981, s. 274.

"1s KKZ, s. 149.

i10 Tamże, s. 150.

11- Bolesław Twardowski (1864-1944), kapł. 1866, studiował we Lwowie i Rzymie. Katacheta, prefekt w seminarium, kanclerz kurii metropolitalnej, rektor seminarium. Od Ły̆ly suragan Iwowski, a od 1923 metropolita. - P. Nitecki, Biskupi.., s. 212.

: KKZ, s. 151 .

: Tamze.

- O. Marceli, Wojciech Surman (1892-1933), do zakonu wstąpił w 1906, kapł. 1914. Ac:ywn dzałacz społecany $i$ charytatywny, wspólpracownik Książęco-Biskupiego Komitetu, apeiza piiali wojskowych. W 1928 inkardynowany do diecezji chełmińskiej. - SPK II $x$ I:- 


\section{XII 1920}

Kanoniczna erekcja III Zakonu Św. Franciszka w parafii zamarstynowskiej ${ }^{122}$.

\section{II pod. XII 1920}

Definitor generalny, o. Eligiusz ${ }^{123}$, podczas wizytacji komisariatu wezwal do Sędziszowa przełożonego i administratora, o. Czesława Szubera, w celu omówienia problemów klasztoru zamarstynowskiego ${ }^{124}$.

\section{IV 1921}

Gwardianem i administratorem parafii został mianowany o. Tadeusz Kraus ${ }^{125}$ na miejsce o. Czesława Szubera ${ }^{126 .}$

\section{VI 1921}

Uroczystość 700-lecia założenia III Zakonu św. Franciszka. Podczas głównych lwowskich uroczystości odbywających się w klasztorze bernardynów kazania głosili o: Honorat Jedliński ${ }^{127}$ i o. Czesław Szuber ${ }^{128}$.

\section{IX 1921}

Podczas uroczystości poświęcenia Mauzoleum pomordowanych przez Ukraińców Polaków kazanie głosił o. Marceli Surman ${ }^{129}$.

\section{$4 \times 1921$}

Erekcja parafii pw. św. Franciszka z Asyżu w miejsce samodzielnej ekspozytury; przekazanie gruntu i majątku kapucynom ${ }^{130}$.

122 AKZ brak sygn. Kronika II Zakonu przy kościele OO. Kapucynów w Zamarstynowie, k. 9.

${ }^{123}$ O. Eligiusz (z Fenne), definitor generalny w latach 1920-1932. - LC 323.

$124 \mathrm{KKZ}$, s. 152.

125 O. Tadeusz, Antoni Stanisław Kraus (1890-1977), do zakonu wstąpił w 1910, kapł. 1916. Kaznodzieja, katecheta, gwardian, spowiednik, misjonarz w Estonii (1933-1966) i thumacz na j. estoński. - SPK I, s. 623-524.

126 ACC (Sędziszów, 7 IV 1921), s. 167. - KPK, s. $10-\mathrm{KKZ}$, s. 152.

${ }^{127}$ O. Honorat, Franciszek Wiktor Jedliński (1869-1952), do galicyjskiej prowincji kapucynów wstapił w 1891, kapł. 1895. Kaznodzieja, wikary i gwardian, rekolekcjonista, misjonarz w Brazylii (1901-1906), działacz polonijny, założyciel wielu szkół polonijnych w Brazylii, legionista, działacz charytatywny, obrońca Polaków w czasie mordów UPA. - SPK I, s. 529-530.

128 KZK, s. 153.

129 Tamże, s. 153.

$130 \mathrm{AZ}$, List Konsystorza Metropolitalnego obrz. łac. w Lwowie do komisarza o. C. Szubera (Lwów, 3 X 1921), k. 49; List Konstystorza Metropolitalnego obrz. łac. we Lwowie 


\section{II 1922}

Uroczystość poświęcenia sztandaru III Zakonu św. Franciszka, istniejącego przy parafii prowadzonej przez kapucynów. Aktu poświęcenia dokonał o. Marceli Surman ${ }^{131}$.

\section{IV 1922}

Wizytacja kanoniczna domu zakonnego, którą przeprowadzil komisarz, o. Czesław Szuber ${ }^{132}$.

\section{VII 1922}

Sufragan lwowski, Bolesław Twardowski, po odprawieniu Mszy św. poświęcił w obecności prowincjała o. Czesława Szubera ochronkę zamarstynowską im. Michała Sklepińskiego ${ }^{133}$ i 400 parafianom udzielił sakramentu bierzmowania ${ }^{134}$.

\section{IX 1922}

O. Antoni Latawiec rozpocząl katechizację w szkole powszechnej ${ }^{135}$.

\section{IX 1922}

Katechetą w szkole powszechnej został mianowany o. Honorat Jedliński ${ }^{136}$.

\section{I 1923}

Na miejsce przeniesionego do Sędziszowa o. Honorata Jedlińskiego przybył o. Gabriel Banaś ${ }^{137}$, który został mianowany wikarym parafii ${ }^{138}$.

do Urzędu Parafialnego w Zamarstynowie (Lwów, 3 X 1921), k. 50; Dekret erekcji kanonicznej nowej parafii obrz. łac. w Zamarstynowie k. Lwowa (Lwów, 4 X 1921), k. 51 -52; List o. T. Krausa do kom. o. C. Szubera (Lwów, 10 X 1921), k. 54.

$131 \mathrm{KKZ}$, s. 154.

in AKZ sygn. 5, Spis..., k. 28v.

13 Michal Sklepiński ( + II/III 1920), naczelnik Gminy Zamarstynów, działacz społeczny. Zabiegal o osiedlenie się kapucynów w Zamarstynowie, oddany kapucynom. Jego rejeniem nazwano jedną $z$ ulic biegnącą obok konwentu kapucynów. - Archiwum Parafii 57. Franciszka w Zamarstynowie - OO. Kapucyni (depozyt w AP), [bez sygn.], Liber Errmorum. 1920, k. nlb 10. - Relacja ustna o. R. Szczalby (Kraków, 25 IV 1966).

- $\mathrm{KKZ}$ s. $154-155$.

- Tamie, s. 155.

- AZ List Kurii Metropolitalnej obrz. łac. we Lwowie do komisarza, o. C. Szubera Ioov. I IX 1922), k. 55.

r O. Gabriel, Jan Banaś (1890-1953), do zakonu wstąpil w 1908, kapl. 1914. Studio- x Ijware Innsbrucku, gdzie uzyskał doktorat. Misjonarz ludowy, katecheta, wikary - geardar Podccas wojny, na Wołyniu bronil ludności polskiej przed bandami UPA. - SPK L. $355-366$.

$=$ ACC (Sedriszów, 10 I 1923), s. 171. - KKZ, s. 155. 


\section{I-3 II 1923}

Wizytacja klasztoru, której dokonal komisarz, o. Czesław Szuber ${ }^{139}$.

\section{1923}

Dokonano zakupu kamienia na budowę świątyni parafialnej ${ }^{\mathbf{1 4 0}}$.

\section{8-23 III 1923}

O. Gabriel Banaś przeprowadził rekolekcje dla dorosłych ${ }^{141}$.

\section{1923}

Remont kaplicy pełniącej rolę świątyni parafialnej ${ }^{142}$.

\section{$6 \mathrm{~V} 1923$}

Msza św. z okolicznościowym kazaniem komisarza, o. Czesława Szubera, i procesja $z$ okazji rocznicy Konstytucji 3 Maja ${ }^{143}$.

\section{0-31 V 1923}

Wizytacja kanoniczna przeprowadzona przez komisarza, o. Czesława Szubera ${ }^{144}$.

\section{1924}

Nominacja o. Gabriela Banasia na stanowisko katechety w Zamarstynowie ${ }^{145}$.

\section{4-9 III 1924}

Rekolekcje dla dorosłych prowadził o. Konstanty Jaron ${ }^{146}$.

\section{6-28 III}

O. Gabriel Banaś przeprowadził rekolekcje dla dzieci ze szkól parafii zamarstynowskiej ${ }^{147}$.

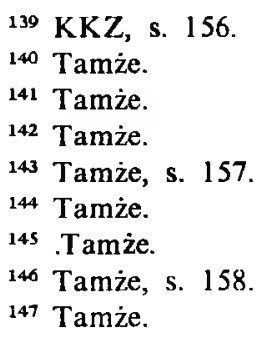




\section{VI 1924}

Utworzenie komitetu budowy kościola parafialnego w Zamarstynowie $\mathrm{z}$ komisarzem gminy Marcinem Wojnarowiczem ${ }^{148}$ jako prezesem ${ }^{149}$.

\section{VII 1924}

Dokonano zmiany na stanowisku przelożonego klasztoru i proboszcza. Przybył o. Aleksander Chmura ${ }^{150}$, który zastąpił o. Krauza ${ }^{151}$.

\section{1924}

Wizytator apostolski, bp Władysław Krynicki ${ }^{152}$, dokonał wizytacji klasztoru zamarstynowskiego ${ }^{153}$.

\section{XII 1924}

Ministerstwo Spraw Wewnętrznych udzieliło zgody br. Szymonowi Nachyle $^{154}$ i br. Makaremu Bieleckiemu ${ }^{155}$ na kwestowanie na budowę kościola w Zamarstynowie ${ }^{156}$.

148 Marcin Wojnarowicz ( + ok. 1950), naczelnik gminy Zamarstynów, pracownik TWS [?]. Wydatnie przyczynił się do wzniesienia kościoła i klasztoru, zaprzyjaźniony z kapucynami. Po 1945 osiadł wraz z rodziną w Bytomiu. - Relacja ustna o. R. Szczałby (Kraków, 25 IV 1996).

149 AZ, List o. T. Krausa do komisarza o. C. Szubera (Zamarstynów, 21 VI 1921), k. $56-57 \mathrm{v} .-\mathrm{KKZ}$, s. 160 .

150 O. Aleksander, Stanisław Chmura (1880-1939), do zakonu wstapił w 1897, kapł. 1903. Duszpasterz, proboszcz i gwardian, społecznik. Zamordowany przez sowietów w Lesienicach k. Lwowa (IX 1939). - SPK I, s. $321-322$.

151 ACC (Kraków, 29 VIII 1924), s. 174. - KPK, s. 18. - KKZ, s. 160.

152 Bp Wladysław Krynicki (1861-1928), duszpasterz, proboszcz i rektor seminarium wlocławskiego, wizytator klaszlorów. Od 1918 sufragan kujawsko-kaliski, do 1927 ordynariusz włoclawski. - P. Nitecki, Biskupi..., s. 115.

153 KPK, s. 15.

154 Br. Szymon, Józef Nachyła (1888-1960), do zakonu wstapił w 1923, a cztery lata póżniej złożył śluby wieczyste. Kwestarz i furtian, wzorowy i pobożny. - SPK II, s. 93.

155 Br. Makary, Szczepan Bielecki (ur. 1881), do komisariatu galicyjskiego kapucynów wstąpił w 1919, śluby wieczyste złożył w 1923. Po dwóch latach opuścił zakon. - SPK I, s. 290.

156 AZ, Zaświadczenie Ministra Spraw Wewnętrznych BP 9683/24 (Warszawa, 7 XII 1924), k. 58; - AP sygn. 35, Akta personalne br. Makarego Bieleckiego, k. 195. - AKZ sygn. 1, Książka inwentarska br. Kaspra Czyrka, s.nlb. 


\section{1924}

Zakupiono i zwieziono pod przyszły kościól kamienie i piasek. Dużą pomoc $w$ pracach transportowych okazało wojsko ${ }^{157}$.

\section{XII 1924}

Rozpoczęto na ulicach Lwowa systematyczną zbiórkę pieniędzy na budowę kościoła w Zamarstynowie, czym zajmowało się 60 tercjarzy i członków róż różańcowych ${ }^{158}$.

\section{XII 1924}

Komitet Budowy Kościoła w Zamarstynowie urządził w budynku gminnym „wieczór sylwestrowy”, z którego dochód przeznaczono na budowę kościola ${ }^{159}$.

\section{I 1925}

Dzieci i młodzież zamarstynowska odegrały ,Jasełka”, z których dochód przeznaczono na budowę kościoła parafialnego ${ }^{160}$.

\section{I 1925}

Założenie dwóch ksiąg kwestarskich na budowę kościoła zamarstynowskiego i rozpoczęcie kwesty przez br. Makarego Bieleckiego w Krośnie i br. Szymona Nachylę w Sędziszowie ${ }^{161}$.

\section{II 1925}

Uroczyste obchody rocznicy wybuchu Powstania Styczniowego, urządzone wspólnie przez kapucynów i Towarzystwo Szkól Ludowych ${ }^{162}$.

\section{II 1925}

Przedstawienie szkolne $\mathrm{w}$ Holosku Wielkim, z którego dochód młodzież przeznaczyła na budowę kościoła parafialnego ${ }^{163}$.

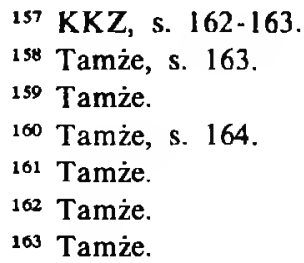




\section{II 1925}

W obecności komisarza, o. Czeslawa Szubera, arch. Jana Sas-Zubrzyckiego ${ }^{164}$ i kierownika budowy Franciszka Kwiecieńskiego ${ }^{165}$ wyznaczono teren pod budowę kościoła ${ }^{166}$.

\section{6-28 III 1925}

O. Gabriel Banaś przeprowadził rekolekcje wielkopostne dla dzieci ${ }^{167}$.

\section{III-6 IV 1925}

O. Feliks, bernardyn ${ }^{168}$, przeprowadził rekolekcje dla parafian ${ }^{169}$.

\section{IV 1925}

$\mathrm{Na}$ placu budowy, na fundamentach kościoła w miejscu wielkiego ołtarza ustawiono i poświęcono krzyż ${ }^{170}$.

\section{IV 1925}

Rozpoczęcie prac przy wznoszeniu ścian świątyni klasztoru kapucynów ${ }^{171}$.

\section{V 1925}

Msza św. polowa i procesja z okazji patrona strażaków, św. Floriana ${ }^{172}$.

164 Jan Karol Sas-Zubrzycki (ur. 1860), archilekt, długoletni inspektor budownictwa w Krakowie, inżynier cywilny architektury i budownictwa lądowego we Lwowie, profesor Politechniki Lwowskiej, autor licznych projektów zabudowy Lwowa, projektant i architekt kosciołów. - S. Loza, Czy wiesz kto to jest? Warszawa 1938, s. 850.

165 Franciszek Kwiecieński ( + przed 1939), mistrz budowlany, zam. we Lwowie. Redacja usina o. R. Szczalby (Kraków 25 IV 1966).

$106 \mathrm{KKZ}$, s. 165.

167 Tamie.

10. Feliks Dwornicki OFM (1877-1975), do Zakonu Braci Mniejszych Prowincji D. Bernardynów wstąpił 14 XI 1896 r., kapł. 1903. rekolekcjonista, redaktor, autor modlitewników. - K. Grudziński OFM, Dwornicki $F$. W: Slownik polskich pisarzy franciszkańskich. Harszawa 1981, s. 118, 119. - APBK. Rkp. RGP-k-30, k. 67.

: $\mathrm{KKZ}$ s. 165.

: Tamie, s. 166.

-7 AGO sygn. G. 49, sec. 2, Sprawozdanie komisarza o. Mariana Najdeckiego do zaradu en. zakonu (Kraków, 4 XII 1928), k.nib. 62. - KPK, s. 18-19. - KKZ, c. 166

$:=\mathrm{KKZ}$, s. 167. 


\section{VI 1925}

Zbiórki pieniężne w całym Lwowie na budowę kościoła parafialnego we Lwowie ${ }^{173}$.

\section{3-6 VII 1925}

Wizytacja klasztoru kapucynów ${ }^{174}$ przez wizytatora generalnego o. Gondulfa Fermota ${ }^{175}$.

\section{VII 1925}

Poświęcenie kamienia węgielnego, fundamentu pod oltarz i murów kościoła przez ks. inf. Wincentego Czajkowskiego ${ }^{176}$ przy bardzo licznym udziale wiernych ${ }^{177}$. Obecny był m.in. wojewoda, Pawel Garapich ${ }^{178}$.

\section{IX 1925}

Pozwolenie Zarządu Generalnego Zakonu na budowę kościoła według przedłożonych planów ${ }^{179}$.

\section{$31 \times 1925$}

Kwesta uliczna we Lwowie na budowę kościola w Zamarstynowie ${ }^{180}$.

173 KKZ, s. 167.

174 KPK, s. 18. - AKZ sygn. 6, Ksiega..., k. 37. - KKZ, s. 168.

175 O. Gondulf (Cyryl), Edward Fermont (1888-1963), Holender, do zakonu wstąpil w 1906, kapł. 1913. Biblista, wykładowca i profesor Pisma św. na KUL, dziekan Wydziału Teologicznego (1945-49), przełożony kom. warszawskjego kapucynów, definitor generalny (1926-32), wizytator generalny obrz. bizantyjsko-słowiańskiego w Polsce od 1931. - SPK I, s. $4 ! 1-412$.

${ }_{176} \mathrm{Ks}$. infułat Wincenty Czajkowski (ur. 1862), kapł. 1884. Dziekan lwowski, prałat domowy Jego Swiątobliwości, oficjał sądu metropolitalnego i egzaminator prosynodalny, wizytator szkół. - Schematyzm Kościola Rzymsko-Katolickiego w Rzeczypospolitej Polskiej. Kraków 1925, s. $154-155$.

177 KKZ, s. 169.

178 Paweł Garapich (ur. 1882), prawnik, starosta w Tarnopolu, nastepnie wojewoda Jwowski. Pełnił różne funkcje społeczne, m.in. kurator Szkoły Gospodarstwa Wiejskiego w Snopkowie, prezes Towarzystwa Rozwoju Ziem Wschodnich. - S. Loza, Czy wiesz..., s. 193.

${ }^{179} \mathrm{ACC}$ (Sędziszów, 20 VIII 1925), s. 176. - AZ, Prośba zarządu kom. skjerowana do generała zakonu o aprobatę planów kościoła (Kraków, 28 VIII 1925), k. 58. - List sekretarza o. Agatanioła do komisarza, o. C. Szubera (Rzym, 12 IX 1925), k. 60.

$180 \mathrm{KKZ}$, s. 170. 


\section{XI 1925}

O. Kosma Lenczowski ${ }^{181}$ mianowany wikarym parafii w Zamarstynowie ${ }^{182}$.

\section{XI 1925}

Oddanie przez gminę parceli przeznaczonej pod kościół i klasztor na wlasność kapucynom ${ }^{183}$.

\section{I 1926}

O. Aleksander Chmura poświęcił Dom Ludowy w Hołosku Wielkim ${ }^{184}$.

\section{I-II 1926}

Prowadzono prace przy zwózce cegły, piasku i drewna na budowę kościoła, którego mury do grudnia 1925 roku wzniesiono do wysokości okien ${ }^{185}$.

\section{II 1926}

Pozwolenie Kongregacji ds. Zakonów na prowadzenie w Zamarstynowie duszpasterstwa parafialnego, określanego jako ,pleno iure regularis” ${ }^{186}$.

\section{0-25 III 1926}

Rekolekcje parafialne przeprowadził o. Kosma Lenczowski ${ }^{187}$.

\section{III 1926}

Uliczna kwesta na budowę kościoła parafialnego w Zamarstynowie, przeprowadzona przez tercjarzy i członków róż różańcowych ${ }^{188}$.

${ }_{181}$ O. Kosma, Karol Lenczowski (1881-1959), do zakonu wstąpił w 1898, kapł. 1905. Kapelan legionowy, spowiednik, działacz społeczny i charylatywny. - SPK I, s. 673-675.

10 ACC (Rozwadów, 3 XII 1925), s. 176. - AZ, Nominacja wikariuszowska Kurii Metropolitalnej we Lwowie dla o. K. Lenczowskiego (Lwów, 17 XI 1925), k. 63.

$10 \mathrm{KKZ}$, s. 171.

ist Tamże, s. 172.

İs ACC (Kraków, 3 XII 1925), k. 177. - KKZ, s. 172.

* AZ, List Kongregacji ds. Zakonów do generała Zakonu Braci Mniejszych Kapucy[0. . . J. Bussolari (Rzym, 26 II 1926), k. 64-65; Paroeciae Ordini concreditae. „Analecta Ordinis Fratrum Minorum Capuccinorum". T. 43 (1927), s. 47.

ir KKZ, s. 172.

* AGO sygn. G. 49, sec. teczka „Conventus loci Zamarstynów” (Zbiór korespondencji pariedzy zarzadem generalnym a Kuria kom. krakowskiego kapucynów, 21 XII 1925-24 V is:), k.nb. 22-48. - Rkp. AH 12, Dokumenty z 11 kongregacji zarządu generalnego 


\section{VI 1926}

Pieniężna zbiórka uliczna na budowę kościoła, prowadzona przez 50 parafian. Zebrano $800 \mathrm{zł}$. W następnych miesiącach prowadzono podobne kwesty uliczne ${ }^{189}$.

\section{1-3 X 1926}

Wizytacja kanoniczna klasztoru przez komisarza, o. Czesława Szubera ${ }^{190}$.

\section{$25 \times 1926$}

Dekretem Kurii Metropolitalnej (na podst. pozwolenia Stolicy Apostolskiej) konwent kapucynów został prawnie połączony $\mathrm{z}$ parafią ${ }^{191}$.

\section{8 (17) XI 1926}

W miejsce kwestarza br. Kaspra Cyrka ${ }^{192}$ zostal wyznaczony br. Lazarz Bogacz ${ }^{193}$ dla zbierania ofiar na budowę kościoła ${ }^{194}$.

\section{XI 1926}

Udekorowanie Krzyżem Walecznych reduty zamarstynowskiej. Uroczysta Msza św. w murach budującego się kościoła, którą odprawił komisarz, o. Czesław Szuber. Obecni byli m.in. gen. Władysław Sikorski i wojewoda Pawel Garapich. Prawne przejęcie przez kapucynów parafii i gruntu, na którym wybudowano budynki klasztorne i parafialne ${ }^{195}$.

Zakonu Kapucynów (Rzym, 30 VI 1926), s. 199. - Dokumenty z 83 Kongregacji..., (Rzym, 27 V 1927), s. 239. - AP Rkp. 16, Księga kasowa Prowincji, $1921-1932$, s. 8, 14, 72 79-80, 82-86, 91, 93-97, 105-106, 108, 110,112,114-119, 125, 129, 130-131, 134. - KKZ, s. 172. $189 \mathrm{KKZ}$, s. 174.

190 Tamże, s. 175.

191 AKZ [bez sygn.], List Kurii Metropolitalnej obrz. lac. we Lwowie do komisarza, o. C. Szubera (Lwów, 25 X 1926).-KKZ, s. 176.

192 Br. Kasper Cyrek (1901-1980), do zakonu wstąpił w 1924, śluby wieczyste złożył w 1929. Kwestarz, zakrystian, furtian. Uczynny i pobożny. - J. Marecki, Kapucyni komisariatu krakowskiego. (Mps w posiadaniu AP), Kraków, s. 20.

193 Br. Lazarz, Paweł Bogacz (1883-1960), do zakonu wstąpił w 1906, śluby wieczyste zlożył w 1914. W latach 1914-18 w armii austriackiej. Organista, ogrodnik, kucharz i kwestarz. - SPK I, s. 294-295.

194 ACC (Kraków, 28 XII 1926), s. 180. - ACP (Kraków, 11 VIII 1927), k. 4.

$105 \mathrm{KKZ}$, s. 176-177. - Semper fidelis..., s. 181. 


\section{III 1927}

Pieniężna kwesta uliczna na budowę kościoła parafialnego, podczas której zebrano 1300 zł. Podobnie jak w poprzednich latach, zbiórki uliczne prowadzono na terenie Lwowa w każdym miesiącu ${ }^{196}$.

\section{8-30 III 1927}

Rekolekcje dla dzieci z parafii zamarstynowskiej przeprowadził o. Kosma ${ }^{197}$.

\section{IV-10 IV 1927}

Ks. dr Teofil Długosz ${ }^{198}$ przeprowadzil parafialne rekolekcje dla dorosłych ${ }^{199}$.

\section{IV 1927}

Aprobata Zarządu Generalnego Zakonu Braci Mniejszych Kapucynów i potwierdzenie planów dla wznoszonego konwentu w Zamarstynowie ${ }^{200}$.

\section{1-3 $\vee 1927$}

Wizytacja kanoniczna konwentu kapucynów przez komisarza, o. Czesława Szubera ${ }^{201}$.

\section{VI 1927}

Kongregacja ds. Zakonów na prośbę komisarza, o. Czesława Szubera, udzieliła pozwolenia na zaciągnięcie pożyczki celem ukończenia budowy konuentu ${ }^{202}$.

\section{VIII 1927}

Zarzad komisariatu przeznaczył do konwentu lwowskiego br. Grzegorza Fereta ${ }^{203}$, zajmują̧ego się ogrodnictwem ${ }^{204}$.

Tamie, s. 173, 187-188, 189, 199, 203, 206, 207, 208, 209, 212.

1or Tamie, s. 180.

1* Ks. Teofil Długosz (ur. 1887), kapł. 1912, dr teologii, katecheta szkolny i kapelan sostr benedyktynek. Po II wojnie światowej zamieszkał w klasztorze karmelitów trzewiczkoweh * Krakowie. - Schematyzm..., s. 173.

in KKZ, s. 180.

2: AGO sygn. AH 12, Uchwaly 76 Kongregacji zarządu generalnego Zakonu Braci Mmejuch Kapucynów, 29 IV 1927, s. 235; Tamże, Uchwaly 82 Kongregacji..,, 20 V 1927, s. 237.

aKZ sygn. 5, Spis..., k. 34. - KKZ, s. 181.

- AZ, List kom., o. C. Szubera, do generała zakonu o. M. Pindea Capo (Kraków, 10 IV 19272, ks. 86; Tamże, Kongregacja ds. Zakonów nr 3593 (Rzym, 1 VI 1927), k. 89.

2x. Grzegorz, Mikołaj Feret (1886-1974), do zakonu wsląpił w 1906, śluby wieczyste zożi = 1921. Ogrodnik, szafarz, zakrystian. SPK I, s. 411.

ACP (Krakow, 11 VIII 1927), k. 4. 


\section{1928}

Do Stanów Zjednoczonych na okres 19 miesięcy wyjechał o. Czesław Szuber, by zbierać ofiary na dokończenie budowy kościola zamarstynowskiego ${ }^{205}$.

\section{VIII 1928}

Po rocznym pobycie br. Grzegorz Feret został odwołany z Zamarstynowa ${ }^{206}$.

\section{VI 1929}

Do wspólnoty konwentu zamarstynowskiego zostal przeznaczony br. Izydor Pułka ${ }^{207}$; objąl obowiązki zakrystiana ${ }^{208}$.

\section{VIII 1929}

O. Józef Borowy ${ }^{209}$ został mianowany katechetą szkoły powszechnej w Zamarstynowie $w$ miejsce o. Antoniego Latawca. Obowiązek ten wypełnial o. Borowy do 1946 roku ${ }^{210}$.

\section{jesień 1929}

Kapucyni zamieszkali w nowo wybudowanym klasztorze ${ }^{211}$.

\section{1929}

Umieszczono na frontonie kościoła kamienną figurę św. Franciszka, dłuta lwowskiego kamieniarza, Ludwika Olszewskiego ${ }^{212}$.

${ }^{205}$ ACP (Kraków, 18 VIII 1928), k. 5v. - ACP (Kraków, 30 XIII 1929), k. 9v. - KPK, s. 27-28.

206 ACP (Kraków, 18 VIII 1928), k. 8v.

$207 \mathrm{Br}$. Izydor Pulka (ur. 1907), do zakonu wstąpił w 1927, śluby wieczyste złożył w 1932. Zajmował się różnymi obowiązkami zakonnymi, m.in. pracował w krakowskiej drukarni klaszlornej „Pokój i Dobro”. Zakon opuścil w 1943. J. Marecki, Kapucyni.., s. 101 .

200 ACP (Kraków, 27 VI 1929), k. 8v.

209 O. Józef, Stanisław Borowy (1904-1977), do zakonu wsląpil w 1922, kapł. 1928. Katecheta, proboszcz i gwardian. SPK 1, s. 301.

210 ACP (Kraków 28 VI 1929), k. 9. -- AP sygn 5, Rozporządzenie konsystorskie. Nominacja Kurii Metropolitalnej obrz. łac. we Lwowie dla o. J. Borowego na stanowisko katechety (Lwów, 10 VIII 1929), k. 347b.

211 KPK, s. 33.

212 Tamże, s. 209. 


\section{IV 1930}

Komisarz, o. Marian Najdecki ${ }^{213}$, przeprowadził wizytację kanoniczną klasztoru ${ }^{214}$.

\section{VI 1930}

Abp Bolesław Twardowski dokonal konsekracji trzech dzwonów (o imionach Aleksander, Czesław, Józef), zakupionych z ofiar parafian ${ }^{215}$.

\section{VII 1930}

W miejsce o. Aleksandra Chmury proboszczem parafii zostal mianowany o. Kosma Lenczowski. Równocześnie do konwentu zamarstynowskiego wyznaczono jako kucharza br. Witalisa Surmana ${ }^{216}$, (którego zastąpił br. Lazarz Bogacz), br. Kaspra Cyrka - furtiana i br. Izydora Pulkę - krawca $^{217 .}$

\section{VII 1930}

O. Aleksander Chmura ponownie mianowany proboszczem parafii ${ }^{218}$.

\section{$5 \times 1930$}

Abp Bolesław Twardowski dokonal konsekracji ołtarza głównego i świątyni parafialnej ${ }^{219}$.

213 O. Marian, Bronisław Najdecki (1876-1951), do zakonu wstapił w 1891, kapł. 1898. Magister nowicjatu, definitor, komisarz prowincji, prefekt kleryków, dyrektor III Zakonu, spowjednik. Asceta i społecznik. SPK II, s. 93-95.

214 AKZ sygn. 5, Spis..., k. $54 \mathrm{v}$.

2is Tamże, s. 211-212.

$216 \mathrm{Br}$. Witalis, Antoni Surma (1864-1936), do zakonu wstąpił w 1887, śluby wieczyste żożył w 1892. Całe życie zakonne pracował jako kucharz. - SPK II, s. 324.

2: ACP (Kraków, 2 VII 1930), k. 13; Tamże (Kraków, 29 XII 1930), k. 13v. - KKZ, 5. 213.

zL ACP (Kraków, 29 XII 1930), k. 14. - KKZ, s. 213.

21 ACP (29 XII 1930), k. 14. - KPK, s. 33-34. - AZ, Zestawienie kosztów robocizny przy budowie kościoła OO. Kapucynów na Zamarstynowie we Lwowie, k. 116. - KKZ, 5. 215; Lwow zbudowal nowy kościól. Uroczystość konsekracji kościola na Zamarstynowie. .L-ow sti Kurjer Poranny” 8 X 1930, s. 3; Konsekracja kościola w Zamarstynowie. „Wiek Nowy- nr 8791 z dn. 8 X 1930 s. 8; Dzien் triumfu cichej pracy. „Lwowskie Wiadomości Paraliahe“. R. 3 (1930), nr 41, s. 1-3; Nowy kościól franciszkañski. „Rodzina Seralicka”. R. = i1951), s. 50-51; W. Szetelnicki, Arcybiskup wygnaniec Eugeniusz Baziak metropolita soosci Krakow 1989, s. 94. 


\section{XII 1930}

O. Bronisław Szepelak, bernardyn ${ }^{220}$, erygowal stacje Drogi Krzyżowej w nowo wybudowanym kościele parafialnym ${ }^{221}$.

\section{XII 1930}

Do klasztoru przybył br. Cyprian Ufnal ${ }^{222}$, który zastąpił br. Izydora Pulkę 223.

\section{IV 1931}

Komisarz, o. Czesław Szuber, dokonał kanonicznej wizytacji konwentu ${ }^{224}$.

\section{VI 1931}

Gmina Zamarstynów została przyłączona do Lwowa ${ }^{225}$.

\section{VI 1931}

Zarząd Komisariatu Krakowskiego Kapucynów zezwolił na wybudowanie domu parafialnego na gruncie klasztornym z funduszów parafialnych ${ }^{226}$.

\section{VI 1932}

Komisarz, o. Czesław Szuber, poświęcił wielki ołtarz i ambonę, wykonane w warsztacie Jana Wojtowicza ${ }^{227}$ w Przemyślanach. W tym samym czasie wyposażono w szafy i klęczniki zakrystię ${ }^{228}$.

220 O. Bronisław, Andrzej Szepelak (1887-1960), do Zakonu Braci Mniejszych Bernardynów wstappil w 1906, kapł. 1914. Gwardian, proboszcz, prowincjał, wizytator generalny zakonu w Polsce, kaznodzieja i misjonarz. - K. Grudziński, Szepelak Bronislaw Andrzej. W: Slownik polskich pisarzy franciszkaniskich. Red. H.E. Wyczawski. Warszawa 1981, s. 478.

$221 \mathrm{KKZ}$, s. 222.

222 Br. Cyprian, Aleksander Ufnal (1866-1945), do zakonu wstapił w 1923 jako członek bezhabitowego Zgromadzenia Sług Maryi, śluby wieczyste złożył w 1927. Szewc, ogrodnik i furtian. SPK II, s. 387.

223 ACP (Kraków, 29 XII 1930), k. 14.

224 AKZ sygn. 5, Spis..., k. 34.

225 Tamze, s. 223.

226 ACP (Kraków, 25 VI 1931), k. 16. - AZ, List komisarza, o. C. Szubera, do konwentu lwowskiego (Kraków, 26 VI 1931), k. 123. - List przełożonego, o. A. Chmury, do komisarza o. C. Szubera (Lwów, 23 IX 1932), k. 129. - List komisarza, o. C. Szubera, do konwentu lwowskiego (Kraków, 27 IX 1932), k. 130. - AKZ sygn. 8, Plany Domu Parafialnego, k. $1-6$.

227 Jan Wojtowicz ( + ok. 1960), artysta rzeźbiarz, właściciel zakładu stolarskiego w Przemyślanach, wykonującego wyposażenje wnętrz kościołów. Po II wojnie światowej osiadł w Tarnowie. Relacja o. R. Szczałby (Kraków, 25 IV 1996).

$228 \mathrm{KKZ}$, s. 223. 


\section{VII 1932}

Kanoniczna wizytacja klasztoru dokonana przez komisarza, o. Czesława Szubera ${ }^{229}$.

1932

Założenie fundamentów pod Dom Parafialny ${ }^{230}$.

\section{IV 1933}

Prymicje kapucyna, o. Serafina Kaszuby ${ }^{231}$ - pierwszego kapłana z terenu parafii zamarstynowskiej ${ }^{232}$.

\section{V 1933}

Kanoniczna wizytacja klasztoru przez komisarza, o. Czesława Szubera ${ }^{233}$.

\section{VII 1933}

Mianowanie o. Ambrożego Mayera ${ }^{234}$ przełożonym klasztoru ${ }^{235}$.

\section{VII 1933}

Nominacja przez metropolitę abpa Bolesława Twardowskiego o. Ambrożego Mayera administratorem parafii, a o. Aleksandra Chmury wikarym parafii ${ }^{236}$.

220 Tamże, s. 224. - AKZ sygn. 5, Spis..., k. 34.

$230 \mathrm{KKZ}$, s. 224.

${ }^{231}$ Sł. Boży o. Serafin, Alojzy Kaszuba (1910-1977), do zakonu wsląpił w 1928, kapl. 1933. Wykładowca - polonista w niższym seminarium, kaznodzieja i rekolekcjonista. Od 1940 duszpasterz na Wołyniu, po 1945 dobrowolnie pozostał w ZSRR, by pracować wśród katolików pozbawionych duszpasterzy. Od 1992 r. toczy się jego proces beatylikacyjny. - SPK I, s. 548-551.

$232 \mathrm{KKZ}$, s. 229. - J. Marecki, Kalendarium życia i dzialalności Slugi Bożego o. Serafina Karsuby. W: Sluga Boży o. Serafin Kaszuha (1910-1977), Kraków 1994, s. 81.

$20 \mathrm{KKZ}$, s. 224. - AKZ sygn. 5, Spis..., k. 34v.

24 O. Ambroży, Gustaw Stanisław Mayer (1902-1961), do zakonu wstapil w 1917, kapł. 1925. Wykladowca i prefekt w niższym seminarium, magister nowicjatu, gwardian, proboszcz, misjonarz ludowy. SPK II, s. 55-57.

2w AP sygn. 11a, Rozporządzenie prowincjałów (Kraków, 17 VII 1933), k. 326.

234 AZ, dekret nominacyjny dla o. A. Mayera, L. 6532/33 (Lwów, 11 VII 1933), k. 133. - ACP (4 VII 1933), k. 23v. - KKZ, s. 224. 


\section{IX 1933}

Parafia zamarstynowska uzyskała pozwolenie od Urzędu Nadzoru Budowlanego Magistratu Miasta Lwowa na budowę Domu Parafialnego ${ }^{237}$.

\section{$1 \times 1933$}

Poświęcenie kamienia węgielnego pod Dom Parafialny ${ }^{238}$.

\section{II/IV 1934}

Rekolekcje dla parafian prowadził o. dr Ludwik Żołnierczyk ${ }^{239}$, kapucyn z Krakowa ${ }^{240}$.

\section{$25 \vee 1934$}

Wizytacja kanoniczna klasztoru przez komisarza, o. Czesława Szubera ${ }^{241}$.

\section{6-26 XI 1934}

Misje parafialne przeprowadzili o. Aniol Madejewski i o. Honorat Jedliński $^{242}$.

\section{IV 1935}

Założenie Akcji Katolickiej w parafii zamarstynowskiej ${ }^{243}$.

\section{V 1935}

Wizytacja kanoniczna klasztoru, dokonana przez komisarza, o. Czesława Szubera ${ }^{244}$.

${ }^{237}$ AKZ sygn. 8, Dom Parafialny (1931-1935), Pozwolenie na budowę Domu Parafialnego (Lwów, 6 IX 1933), k. 1-2.

${ }^{238} \mathrm{KKZ}$, s. 197.

239 O. Ludwik, Antoni Źołnierczyk (1896-1960), do prowincji galicyjskiej wstąpił w 1911, kapł. 1919. Studiowal w Krakowie, Rzymie i Innsbrucku, dr prawa kanonicznego. Wykładowca, gwardian, proboszcz, reklor seminarium, definitor. SPK II, s. $483-484$.

$240 \mathrm{KKZ}$, s. 226.

241 AKZ sygn. 5, Spis..., k. 34v. - Tamże, sygn. 6, Ksiega..., k. 97. - KKZ, s. 226.

${ }^{242}$ AKZ [bez sygn.], Zawiadomienie o misjach parafialnych (ulolka), Lwów 1934.

${ }^{243} \mathrm{KKZ}$, s. 226.

244 AKZ sygn. 5, Spis... k. 34v. - KKz, s. 227. 


\section{VI 1935}

O. Ambroży Mayer został zwolniony $\mathrm{z}$ obowiązków administrowania parafią. W jego miejsce mianowany zostal o. Aleksander Chmura ${ }^{245}$.

\section{1935}

Prymicje ks. Mariana Maścińskiego ${ }^{246}$ z kazaniem o. Serafina Kaszuby ${ }^{247}$.

\section{VII 1935}

Do wspólnoty zakonnej dołączyli o. Roman Bałut ${ }^{248}$ i br. Krzysztof Zaborski ${ }^{249}$ przeniesieni z Kutkorza ${ }^{250}$.

\section{6-7 VIII 1935}

Wizytacja konwentu przez Generała Zakonu Braci Mniejszych Kapucynów, o. Wigiliusza dalla Zuana ${ }^{251}$, i regionalne spotkanie kapłanów z klasztorów w Olesku, Kutkorzu i Drohobyczu ${ }^{252}$.

\section{XI 1935}

Bp Eugeniusz Baziak ${ }^{253}$ poświęcił przeznaczony do głównego ołtarza obraz z wyobrażeniem św. Franciszka z Asyżu - patrona kościoła, parafii i para-

245 ACP (20 VI 1935), k. 28-29. - AZ, prośba komisarza, o. C. Szubera, do Kurii Metropolitalnej obrz. łac. we Lwowie o zmianę administratora paralii (Kraków, 2 VI 1935), k. 141. - Dekret nominacyjny na administratora parafii dla o. A. Chmury (Lwów, 6 VI 1935), k. 143. - List komisarza, o. C. Szubera, do o. A. Chmury (Kraków, 21 VII 1935), k. 144. - KKZ, s. 228.

240 Ks. Marian Mościński (ur. 1910), kapł. 1935, po Il wojnie światowej w diecezji wroclawskiej. Relacja o. R. Szczałby (Kraków, 26 IV 1996).

${ }^{247} \mathrm{KKZ}$, s. 229 .

248 O. Roman, Antoni Bałut (1898-1941), do zakonu wstapił w 1901, kapl. 1915. Gwardian, proboszcz, działacz społeczny i palriotyczny. Zamordowany przez NKWD. SPK I, s. 264.

2+9 Br. Krzysztof, Stanisław Zaborski (ur. 1908), do zakonu wstapił w 1927, śluby wieczyste w 1931. Dekret sekularyzacyjny otrzymał 1939. J. Marecki, Kapucyni..., s. 127. $250 \mathrm{KKZ}$, s. 228.

2s1 O. Wigiliusz dalla Zuana (1880-1960), do zakonu wstapił w 1896, kapł. 1904. Wylładowca seminarium, przełożony, prowincjał, general zakonu w latach 1932-1938, w 1941 mianowany bpem Capri (Włochy). - LC, k. 487.

20 AGZ sygn. G. 49, sec. 2, List generała zakonu o. Wigiliusza do komisarza, o. C. Szubera (Rzym, 25 VI 1935), k.nlb. 86. - KPK, s. 47-48. - AKZ sygn. 6, Ksiega.., k. 101. - KKZ s. 228-229.

2s Abp Eugeniusz Baziak (1890-1962), kapł. 1912, bp 1933. Wikariusz, kapelan wojstowy. proboszez i dziekan, rektor seminarium, sufragan a potem melropolita lwowski, od 195I koadiutor kard. A. S. Sapiehy w Krakowie, administrator apostolski tamże. P. Nitecki, Bxicazi... S. 26. 
fialnej Akcji Katolickiej, namalowany przez artystę malarza o. Efrema Klawittera ${ }^{254}$, kapucyna $\mathrm{z}$ Belgii ${ }^{255}$.

\section{III-5 IV 1936}

Rekolecje dla parafian prowadził o. dr Ludwik Żołnierczyk, kapucyn ${ }^{256}$.

\section{8-20 IV 1936}

Wizytacja kanoniczna konwentu, przeprowadzona przez komisarza, o. Czesława Szubera ${ }^{257}$.

\section{VI 1936}

Bp Bolesław Twardowski poświęcił Dom Parafialny w obecności wojewody lwowskiego Sobańskiego, starosty Eckarta i prezydenta miasta Ostrowskiego. W budynku znalazły się pomieszczenia dla Akcji Katolickiej, bractw parafialnych, biblioteki, sali teatralnej i dla ubogich ${ }^{258}$.

\section{VII 1936}

Mianowanie o. Waleriana Bulca ${ }^{259}$ kooperatorem parafii $w$ miejsce o. Kosmy Lenczowskiego ${ }^{260}$.

\section{VII 1936}

O. Wladysław Zając ${ }^{261}$ został mianowany przełożonym klasztoru i proboszczem w miejsce o. Aleksandra Chmury. O. Czesław Szuber zostal mianowany wikarym konwentu, a 0 . Walerian Bulec wikarym parafii ${ }^{262}$.

254 O. Efrem, Stanisław Klawitter (1849-1970), do zakonu wsląpił w 1920, kapł. 1925. Alumn prowincji galicyjskiej, potem belgijskiej, a następnie warszawskiej kapucynów. Artysla-malarz, portrecista. SPK I, s. 559-565.

255 ACP (Kraków, 27 XII 1935), k. 32. - KKZ, s. 230. - SPK I, s. 562( bibl. podmiotowa $\mathrm{nr} 26$ ).

${ }^{256} \mathrm{KKZ}$, s. 234.

${ }^{257}$ AKZ sygn. 5, Spis..., k. 34v. - Tamże, sygn. 6, Ksiega..., k. 108v. - KKZ, s. 234.

258 AGZ sygn. G. 49, sec. 2, Relatio de statu Cammissariatus Cracoviensis facta visitatione provinciali 1936 (Cracoviae, 4 Junii 1936), nr 207/36, k.nlb. 130. - KKZ, s. 234-235.

259 O. Walerian, Jan Bulec (1900-1993), do zakonu wstąpił w 1926, kapł. 1933, od 1952 w diecezji siedleckiej. Katecheta, wikariusz i proboszcz. J. Marecki, Kapucyni..., s. 13.

$200 \mathrm{AZ}$, Nominacja Kurii Metropolitalnej obrz. lac. we Lwowie dla o. K. Lenczowskiego, nr 6226 (Lwów, 12 VIII 1936), k. 147.

${ }_{261}$ O. Władysław, Andrzej Zając (1889-1966), do zakonu wstąpił w 1909, kapł. 1916. proboszcz, gwardian, działacz społeczny. SPK II, s. 454-545.

${ }^{262} \mathrm{AZ}$, Dekret nominacyjny Kurii Metropolitalnej obrz. łac. we Lwowie dla o. A. Zająca, nr 5887 (Lwów, 31 VII 1936), k. 145. - ACP (Kraków, 20 VII 1936), k. 35 v. 


\section{VI/VIII 1936}

Rozbiórka tymczasowej kaplicy parafialnej, która przez ostatni rok służyła jako kaplica pogrzebowa ${ }^{263}$.

\section{IX 1936}

O. Walerian Bulec z liczącą 150 osób grupą pielgrzymkową parafian zamarstynowskich udał się do Milatyna ${ }^{204}$.

\section{II/III 1937}

Rozpoczęcie pracy duszpasterskiej w kaplicy w Zboiskach, należącej do parafii w Malechowie ${ }^{265}$.

\section{III 1937}

Poświęcenie obrazu-św. Piotra pędzla Jadwigi Rymarówny ${ }^{266}$, który to obraz umieszczono w zwieńczeniu ołtarza glównego ${ }^{267}$.

\section{4-21 III 1937}

Rekolekcje dla parafian prowadził o. Bernard Filip ${ }^{268}$, katecheta z Kutkorza ${ }^{269}$.

\section{III 1937}

O. Czesław Szuber poświęcił kaplicę w zakładzie Braci Albertynów ${ }^{270}$.

- KKZ, s. 235. - AKZ [bez sygn.], A[nna] B[aygerowa], Na pożegnanie (wiersz dedykowany

o. Chmurze), 2 VII 1936.

$263 \mathrm{KKZ}$, s. 238.

264 Tamże.

205 AP sygn. 5, Rozporzqdzenia..., Prośba abpa B. Twardowskiego do komisarza o. G. Rysza (Lwów, 24 II 1937), k. 352.

206 Jadwiga Rymarówna (1911-1995), córka senatora Stanisława Rymara, absolwentka Akademii Sztuk Pięknych w Krakowie. Namalowała szereg obrazów o tematyce religijnej. Por. J. Kuś, Stanislaw Rymar (1886-1965). Kraków 1986, s. 4. $207 \mathrm{KKZ}$, s. 239.

260 O. Bernard, Stanisław Filip (1900-1987), do zakonu wstąpił w 1924, kapł. 1932.

Katecheta, proboszcz, spowiednik i kaznodzieja. SPK I, s. 415-416.

$200 \mathrm{KKZ}$, s. 239.

200 KKZ, s. 239. 


\section{IV 1937}

O. Remigiusz Kranc ${ }^{271}$ mianowany kooperatorem parafii z obowiązkiem prowadzenia duszpasterstwa w Zboiskach ${ }^{272}$.

\section{7-19 IV 1937}

Pierwsza wizytacja duszpasterska parafii dokonana przez abpa Boleslawa Twardowskiego ${ }^{273}$.

\section{VI 1937}

Komisarz, o. Gerard Rysz ${ }^{274}$, przeprowadził wizytację kanoniczną konwentu ${ }^{275}$.

\section{VII 1937}

O. Bogumił Marecki w miejsce o. Waleriana Bulca mianowany kooperatorem w Zamarstynowie ${ }^{276}$.

\section{VIII 1937}

Pielgrzymka parafian zamarstynowskich do Milatyna, gdzie młodzież odegrała sztukę teatralną „Męka Pańska"277.

\section{$21 \times 1937$}

Inauguracja spotkań teatralnych i sceny w Domu Parafialnym, podczas której młodzież z Akcji Katolickiej odegrała sztukę pt. „Genowefa” ${ }^{278}$.

271 O. Remigiusz, Bolesław Kranc (1910-1977), do zakonu wstąpil w 1926, kapł. 1933. Katecheta, proboszcz, gwardian i prowincjał. W latach 1943-45 otoczył opieka Polaków zagrożonych ze strony UPA, komendant obrony Ostroga, kapelan AK. W latach 1945-49 w lagrach nad Kolymą. SPK I, s. 619-620.

272 AAL sygn. 1050, Pismo Kurii Metropolitalnej obrz. łac. we Lwowie do 0 . $R$. Kranca, nr 2580/37 (Lwów, 3 IV 1937). - KPK, s. 55. - KKZ, s. 239.

${ }^{273}$ ACP (Kraków, l VII 1937), k. 38-38v. - AKZ [bez sygn.], Księga III Zakonu św. Franciszka (w Zamarstynowie), k. 5. - KKZ, s. 239-241.

274 O. Gerard, Józef Rysz (1892-1978), do zakonu wstąpił w 1911, kapł. 1917. W życiu zakonnym petnił wiele funkcji, m.in. był przełożonym, magistrem nowicjalu, proboszczem, dyrektorem niższego seminarium, delinitorem i prowincjałem. Pełnił funkcję prezesa Rady Glównej III Zakonu św. Franciszka w Polsce w latach 1936-39. - SPK II, s. 245-247.

${ }^{275}$ AKZ sygn. 5, Spis..., k. 35. - Tamże, sygn. 6, Ksiega.., k. 112. - KKZ, s. 241.

276 AP sygn. 5, Rozporzadzenia..., Akl nominacyjny Kurii Metropolitalnej obrz. lac. we Lwowie dla o. B. Mareckiego (Lwów, 27 VII 1937), k. 353. - ACP (Kraków, 2 VII 1937), k. $38 \mathrm{v},-\mathrm{KKZ}$, s. 242 .

$277 \mathrm{KKZ}$, s. 242.

278 Tamże. 


\section{I 1938}

O. Marek Kolbuszowski ${ }^{279}$ został mianowany kooperatorem parafii w miejsce przeniesionego do Krakowa o. Remigiusza Kranca ${ }^{280}$.

\section{1938}

Stolarz, br. Walenty Broda ${ }^{281}$, ukończyl pracę nad wyposażeniem Domu Parafialnego, m.in. wykonal 200 krzeseł do sali teatralnej ${ }^{282}$.

\section{IV 1938}

Założono w parafii Bezprocentową Kasę Pożyczkową ${ }^{283}$.

\section{9-30 IV 1938}

Komisarz, o. Gerard Rysz, przeprowadził wizytację kanoniczną klaszto$\mathrm{ru}^{284}$.

\section{IX 1938}

Zmiana w obsadzie personalnej w klasztorze: br. Metody Łuszcz $^{285}$ zastąpił br. Szczepana Jasnochę ${ }^{286}$, kucharza ${ }^{287}$.

\section{IX 1938}

Coroczną pielgrzymkę parafian do Milatyna zorganizował i prowadzil o. Bogumil Marecki ${ }^{288}$.

${ }^{279}$ O. Marek, Piotr Kolbuszowski (1910-1992), do zakonu wstapił w 1928, kapl. 1936, do 1958 w diecezji gdańskiej. Prefekt, proboszcz, duszpasterz, poeta. - SPK I, s. 584-585. $280 \mathrm{KKZ}$, s. 243.

281 Br. Walenty, Andrzej Broda (1907-1994), do zakonu wstąpił w 1934, śluby zakonne w 1938. Stolarz, pisarz ascetyczny. - SPK I, s. 302-303.

${ }^{292} \mathrm{KKZ}$, s. 243.

283 Tamże.

284 AKZ sygn. 5, Spis..., k. 35. - KKZ, s. 245.

28s Br. Metody, Stanisław Małopolski (ur. 1917), do zakonu wstąpił w 1937. W jesieni 1940 olrzymal zwolnienie ze ślubów czasowych. J. Marecki, Kapucyni..., s. 69.

280 Br. Szczepan, Jan Edward Jasnocha (1905-1967), do zakonu wstąpił w 1933, śluby wieczyste w 1938. Kucharz, furtian, zakrystian w Loreto. Aresztowany przez NKWD w 1940 wsapil do armii gen. Andersa, z którą przeszedł cały szlak bojowy. W latach 1946-1966 w Loreto. - SPK I, s. 523-524.

2ar ACP (Kraków, 29 XII 1938), k. $41 \mathrm{v}$.

2an $\mathrm{KKZ}$, s. 246. 


\section{XI 1938}

Wmurowanie na zewnętrznej ścianie kościoła i poświęcenie pamiątkowej tablicy ku czci Obrońców Lwowa broniących odcinka Kleparów-Zamarstynów w 1918 r.; wśród zaproszonych gości obecni byli: gen. Władysław Langner ${ }^{289}$ oraz przedstawiciele wladz miejskich ${ }^{290}$.

\section{III-2 IV 1939}

Rekolekcje parafialne glosił komisarz, o. Gerard Rysz ${ }^{291}$.

\section{V/VI 1939}

Poświęcenie kaplicy w szpitalu przeciwgruźliczym w Hołosku Wielkim ${ }^{292}$.

\section{V 1939}

Prymicje o. Innocentego Trojanowskiego, kapucyna z Holoska Małego ${ }^{293}$.

\section{VI 1939}

Ukończenie budowy krypty przy kościele dla sprawowania nabożeństw przy zmarlych ${ }^{294}$.

\section{VI 1939}

Nominacja o. Bogumiła Mareckiego na stanowisko proboszcza i opiekuna III Zakonu św. Franciszka, a o. Czesława Szubera na gwardiana (20 VI 1939) w miejsce o. Władysława Zająca, pełnięcego dotychczas obydwa obowiązki. Mianowanie o. Kosmy Lenczowskiego ekonomem, o. Eusta-

289 Wladysław Langner (1896-1972), oficer austriacki, legionista, do 1833 general, komendant garnizonu wojskowego we Lwowie, komendant obrony Lwowa we wrześniu $1939 \mathrm{r}$. Następnie w PSZ na Zachodzie. - W. Langner, Ostatnie dni obrony Lwowa. W: Wrzesień 1939 w relacjach $i$ wspomnieniach. Warszawa 1989, s. 694-713. - J. Węgierski, Lwów pod okupacjq sowieckq. 1939-1941. Warszawa 1991, s. 370-371.

290 AAL, teczka „Zamarstynów”. Pozwolenie na wmurowanie pamiąlkowej tablicy (Lwów, 24 X 1938). - AP [bez sygn.], Prośba konwentu lwowskiego o pozwolenie na wmurowanie pamiątkowej tablicy, k. 5. - KKZ, s. 248.

$291 \mathrm{KKZ}$, s. 251.

292 AKZ [bez sygn.], Pozwolenie Kurii Metropolitalnej obrz. lac. na poświęcenie kaplicy w lecznicy (Lwów, 31 V 1939), k. 1.

${ }^{293} \mathrm{KKZ}$, s. 251.

294 Tamże, s. 252. 
chego Rzepki 295 wikarym parafii, a o. Adama Zachowicza ${ }^{296}$ duszpasterzem przy kościele w Zboiskach ${ }^{297}$.

\section{IX 1939}

Przybycie pierwszych ,uciekinierów” z ziem zachodnich i kapucynów z Krakowa i Sędziszowa do lwowskiego klasztoru kapucynów ${ }^{298}$.

\section{IX 1939}

Prowincjał, o. Kazimierz Niczyński ${ }^{299}$, mianowal II definitora i przełożonego klasztoru we Lwowie, o. Czesława Szubera, swoim delegatem dla klasztorów na ziemiach zajętych przez Armię Czerwoną ${ }^{300}$.

\section{IX 1939}

Armia Czerwona wkroczyła do Lwowa-Zamarstynowa ${ }^{301}$.

\section{1939}

Klasztor zamienił się w „dom uciekinierów” - do wiosny następnego roku przez konwent lwowski przewinęli się prawie wszyscy klerycy i nowicjusze prowincji krakowskiej kapucynów (około 80 osób), którym władze zakonne poleciły w pierwszych dniach wojny udać się do klasztorów wschodnich celem kontynuowania nauki ${ }^{302}$.

O. Romuald Szczałba ${ }^{303}$ objął funkcję kapelana Sióstr Wieczystej Adoracji Najśw. Sakramentu przy ul. Kurkowej, którą pelnił do VII 1940. Rónocześnie spelnial obowiązki wikariusza przy kościele pw. Św. Antoniego ${ }^{304}$.

O. Eustachy, Tomasz Rzepka (19l8-197), do zakonu wstapił w 1933, kapł 1941. Kalechela, gwardian i misjonarz ludowy. - SPK II, s. 260.

- O. Adam, Tadeusz Zychowicz (ur. 1908) do zakonu wstąpił w 1925 . hapł. 1932.

Kalocheta, proboszcz. W 1948 "1: statum la alem - SPK II, s. 480-481.

ACP (Kraków, 20 VI 14.39), k. 45v. - SíK II, s. 48, 334, 481.

200 Por. J. Mariki, Dzieje..., s. 218-220, 382 .

- O. Kazimier! Idam Józef Niczýnski (|x97-1979), do zakonu wstạul 1921. kapł. 1926. gwardian, delinıtor, prowincjał, reholehcjonista, kaznodzieja i misjullarz ludowy. - SPK II, s. $102-103$.

3GO sygn. G. 69, sec. 6, List prowincjała o. K. Niczyńskiego do generała zakonu

o. D. a Velle (Kraków, 20 X 1940), k.nlb. 3-4. - KPK, s. 59.

301. Heggierski, Lwów..., s. 11.

ACP (Kraków, 19 I 1940), k. 47-47v. - J. Marecki, Dzieje..., s. 321.

O. Romuald, Józef Szczałba (ur. 1915), do zakonu wstąpił w 1932, kapł. 1939.

H okresie wojny kapelan franciszkanek (pod nazwiskiem Roman Romanek), wikariusz i duszpasterz, katecheta, do 1951 sekretarz prowincjalny. - SPK II, s. 328-329.

304 SPK II, s. 328. - J. Marecki, Dzieje..., s. 283. 
O. Serafin Kaszuba otoczył opieką duszpasterską wiernych gromadzących się w kaplicy Akademii Rolniczej w Dublanach (do XII 1939) ${ }^{305}$.

\section{1939-1941}

Dom Parafialny zamieniono na dom noclegowy dla „bieżeńców”, a następnie na bursę dla uczniów szkoły ogrodniczej ${ }^{306 .}$

\section{VI 1940}

Nocna rewizja w klasztorze, przeprowadzona przez patrol NKWD, aresztowanie o. Albina Janochy ${ }^{307}$, kl. Lukasza Szypuly ${ }^{308}$ i br. Fabiana Reguły ${ }^{30}$ jako „osobników społecznie niebezpiecznych” i zesłanie ich na okres 5 lat do obozu pracy ${ }^{310}$.

\section{pol. 1940}

Otwarcie przez proboszcza, o. Bogumila Mareckiego, kuchni dla ubogich parafian, która z czasem weszła w skład tzw. Kuchni Ludowych otrzymując $\mathrm{nr} 14^{311}$.

305 J. Marecki, Kalendarium..., s. 82.

${ }^{306}$ T. Gorczyca, Moja dzialalność..., s. 10; Br. D. Tomiczek, Relacja usına (Knittefeld - Austria, 10 VI 1991).

307 O. Albin, Franciszek Janocha (ur. 1912), do zakonu wsląpił w 1929, kapł. 1936. Spowiednik, kapelan wojskowy, duszpasterz sybiraków, delinitor, rektor seminarium zakonnego. W latach 1940-1956 w armii gen. Andersa, w więzieniu i na Syberii. - SPK I, s. $516-517$.

${ }^{308}$ Kl. Lukasz, Piotr Szypula (ur. 1919), do zakonu wstapił w 1937, student WSD Kapucynów w Krakowie, w 1940 aresztowany przez NKWD, od 1944 w wojsku. Po wojnie nie wrócił do życia zakonnego. J. Marecki, Kapucyni.., s. 116.

309 Br. Fabian, Ludwik Reguła (ur. 1919), do zakonu wstąpił w 1928, șluby wieczyste złożył w 1932. Kucharz i furtian. Aresztowany w 1940 przez NKWD zaginą na Syberii. - SPK 1, s. 213.

310 AGO sygn. G. 49, sec. 6, List prowincjała o. K. Niczyńskiego do generała zakonu (Kraków 20, X 1940), k.nlb. 3-4. - Tamże. sygn G. 49, sec. 2, List prowincjała, o. K. Niczyńskiego, do Kurii Generalnej (Kraków 29 IX 1941), k.nlb. 25. Tamże, sygn. G. 49, sec. 3, List prowincjała o. H. Warachima do Kurii Generalnej (Kraków, 17 I 1966), k.nlb. 44. - KPK, s. 59, 6a. - A. Janocha, Pod opiekq Matki Bożej. Wroclaw 1993, s. 21.

311 AAL, teczka „Polski Komitel Opieki”, Dotacje dla kuchni ludowych w XII 1943, k.nlb. 40. - Wykaz kuchni ludowych, k.nlb. 45. - J. Marecki, Dzieje..., s. 325-327. 


\section{VI 1941}

Zajęcie Lwowa przez wojska niemieckie. W klasztorze zamieszkali o. Hieronim Warachim ${ }^{312}$, o. Florian Nestorowski ${ }^{313}$ i o. Romuald Szczalba $^{314}$.

\section{1942}

Gwardianem klasztoru w miejsce o. Czesława Szubera został mianowany o. Florian Nestorowski ${ }^{315}$.

\section{VII 1942}

Objęcie przez o. Tytusa Gorczyce ${ }^{316}$, w miejsce o. Adama Zychowicza, obowiązków duszpasterza w Zboiskach ${ }^{317}$.

\section{1942}

Obowiązki proboszcza w miejsce o. Bogumila Mareckiego przejął o. Florian Nestorowski ${ }^{318}$.

\section{1943}

O. Innocenty Trojanowski otoczył opieką duszpasterską kaplicę Akademii Rolniczej w Dublanach (do VII 1945) ${ }^{319}$.

312 O. Hieronim, Karol Warachim (ur. 1916), do zakonu wstapił w 1931, kapł. 1939. Duszpasterz, gwardian, prowincjał. - SPK II, s. 395-397.

313 O. Florian, Józel Nestorowski (1912-1988), do zakonu wsląpił w 1930, kapł. 1939. Katecheta, proboszcz, gwardian, kaznodzieja. - SPK II, s. 99-100.

314 ACP (Kraków, 30 VIII 1942), k. 50. - J. Węgierski, Lwów..., s. 273.

${ }^{315}$ AAL sygn. 106, Księga indeksowa. 1942, nr 2048, 2066, 2084 2142. - ACP (Kraków, 30 VI 1942), k. 50v. - SPK I, s. 190.

316 O. Tylus, Franciszek Gorczyca (1913-1981), do zakonu wsląpił w 1930. kapł. 1939. Katecheta, proboszcz, kapelan szpitalny, spowiednik, z zamiłowania malarz. - SPK I, s. 456-458.

317 AAL sygn. 107, Księga indeksowa. 1943, nr 4870. - Tamże, sygn. 1050, Prośba prowincjała, o. K. Niczyńskiego, o zwolnienie $z$ obowiązków duszpasterskich o. A. Zychowicza i mianowanie o. T. Gorczycy (Kraków, 17 VII 1942), nr 2048. - AZ, List o. T. Gorczycy do prowincjała o. K. Niczyńskiego (Lwów, 25 VlI 1942), k. 181. - J. Marecki, Dzieje..., s. 273 .

318 ACP (Kraków, 30 VI 1942), k. 50v. - Schematismus Archidioecesis Leopoliensis Rit. Lat. (Lwów) 1943, mps, snlb. 8. - J. Marecki, Dzieje..., s. 253.

319 AAL sygn. 107, Księga indeksowa. 1943, nr 1085. - J. Marecki, Dzieje..., s. 526. 


\section{IV 1943}

Akcja odbicia więźniów (w tym rektora seminarium, ks. Stanisława Frankla) ${ }^{320}$ ze szpitala więziennego na terenie Zamarstynowa, w której to akcji brali udział kapucyni. Po ucieczce $z$ więzienia ks. Frankl przez kilka godzin ukrywal się w klasztorze kapucynów ${ }^{\mathbf{3 2 1}}$.

\section{VII 1943}

Po rezygnacji o. Hieronima Warachima zarząd prowincji mianował o. Romualda Szczałbę ekonomem klasztoru ${ }^{\mathbf{3 2 2}}$.

\section{VIII 1943}

Zakończenie przez o. Tytusa Gorczycę działalności duszpasterskiej w kościele w Zboiskach, należącym do parafii Malechów ${ }^{323}$.

\section{XII [?] 1943}

Objęcie przez o. Floriana Nestorowskiego opieki nad pozbawioną duszpasterzy parafią Malechów, sąsiadującą z terenem parafii obsługiwanej przez kapucynów. Jako kooperatorzy zostali mianowani o. Walerian Bulec i o. Innocenty Trojanowski, którzy wkrótce wyjechali na Ziemie Zachodnie ${ }^{324}$.

\section{pol. 1944}

O. Romuald Szczałba został mianowany wikarym parafii zamarstynowskiej $^{325}$.

320 Ks. Stanisław Frankl (1903-1944), kapl. 1927, teolog, rektor seminarium we Lwowie, docent Wyższego Teologicznego Uniwersytetu Lwowskiego, członek podziemia. - W. Urban, Droga krzyżowa archidiecezji lwowskiej w latach II wojny światowej. 1939-1945. Wrocław 1983, s. 10 .

${ }_{321}$ W. Szetelnicki, Zapomniany lwowski bohater ks. Stanislaw Frankl (1903-1944). Roma 1983, s. 157-160; J. Marecki, Dzieje..., s. 308.

322 ACP (Kraków, 15 VII 1943), k. 52.

323 AAL sygn. 106. Księga indeksowa. 1942, nr 531. - Sygn. 1050, prośba prowincjała, o. K. Niczyńskiego, do Kurii Metropolitalnej o zwolnienie z prac duszpasterskich $w$ Zboiskach (Kraków, 3 VIII 1943), nr 3196. - AZ, List abpa B. Twardowskiego do Urzędu Prowincjalskiego OO. Kapucynów w Krakowie (Lwów, 12 VII 1943), k. 178. - List o. F. Nestorowskiego do Kurii Metropolitalnej obrz. lac. we Lwowie (Lwów, 25 VII 1943), k. 180. - List o. T. Gorczycy do prowincjala, o. K. Niczyńskiego (Lwów, 25 VII 1943), k. 181. J. Marecki, Dzieje..., s. 525.

324 Relacja ustna o. Romualda Szczałby (Kraków, 25 IV 1996).

32s AAL sygn. 108, Księga indeksowa. 19944, nr 3615. 


\section{VII 1944}

Powtórne zajęcie Lwowa przez Armię Czerwoną.

\section{1945}

Pierwsza grupa kapucynów (o. Czesław Szuber, o. Tytus Gorczyca i br. Lazarz Bogacz) opuściła klasztor zamarstynowski, udając się do Krakowa ${ }^{326}$.

\section{IV 1946}

W kolejnej grupie „repatriowanych" opuścil Lwów br. Dydak Tomiczek $^{327}, \mathrm{z}$ inwentarzem klasztornym ${ }^{328}$.

\section{I pot. V 1946}

Wraz z mieszkańcami parafii Malechów opuścił Lwów o. Walerian Bulec 329 .

\section{V 1946}

Pożegnanie parafian podczas ostatniego nabożeństwa majowego przez o. Romualda Szczałbę ${ }^{330}$.

\section{V 1946}

Ostatnie Msze św. w świątyni parafialnej. Opuszczenie klasztoru i kościoła. Deportacja ostatnich zakonników (o. Romualda Szczalby, o. Floriana Nestorowskiego, o. Józefa Borowego i br. Walentego Brody) do Krakowa. Przywieźli ze sobą część sprzętów klasztornych i wyposażenie zakrystii. Zajęcie klasztoru przez żołnierzy radzieckich ${ }^{331}$.

320 KKK IV, s. 368. - APZ sygn. 55, T. Gorczyca, Moja dzialalność duszpasterska w okresie II wojny swiatowej 1939-1945 (mps), Kraków [brw], s. 11. - R. Szczalba, Opuszczamy Lwów, s. 14.

${ }^{327} \mathrm{Br}$. Dydak, August Tomiczek (1914-1994), do zakonu wstąpił w 1932, śluby wieczyste $w$ 1936. Socjusz prowincjalny, zakrystian, kucharz, długoletni szafarz w klasztorze kapucynów w Krakowie. - J. Marecki, Kapucyni..., s. 118.

${ }^{328}$ AKZ [bez sygn.], Sprawka; poswidka (dokumenty w jęz. rosyjskim), k. 1-3. - AKZ [bez sygn.], Spis aparalów kościelnych przywiezionych ze Lwowa (Kraków, 23 VI 1946), k.nlb. 1 .

329 J. Marecki, Dzieje..., s. 526. - Relacja usına o. R. Szczałby (Kraków, 10 III 1990).

330 APZ [bez sygn.], R. Szczalba, Opuszczamy Lwów, s. 5. - J. Marecki, Dzieje..., s. 396.

331 AGO sygn. G. 59, sec. 3, List prowincjała, o. K. Niczyńskiego, do generała zakonu o. K. Neubauera (Kraków, 15 VI 1946), k.nlb. 35. - APZ [bez sygn.], R Szczałba, Opuszczamy Lwów, s. 14. - J. Marecki, Dzieje..., s. 394. 